\title{
International Investment Law and Noneconomic Issues
}

\author{
Barnali Choudhury*
}

\begin{abstract}
Arbitral tribunals have misconstrued the purpose of international investment agreements (IIAs) by failing to factor in the development aspect of these agreements into their analysis. IIAs were constituted to protect foreign investment in order to promote economic development. However, arbitral tribunals have tended to focus mainly on the investor protection elements of IIAs, leading to impingements on human rights and the environment and leaving IIAs as a threat to sustainable development.

Drawing from all publicly available investment awards, a review of these awards found fifty-six awards in which human rights and environmental issues were implicated in investment disputes. The review further finds that in many instances arbitral tribunals downplay or dismiss noneconomic issues, leaving compromises to both human rights and environmental issues and constraints on state ability to regulate these areas. Based on the findings of this review, the Article makes suggestions for how states can best reform IIAs to help them better align with the development aspects of these agreements.
\end{abstract}

\section{TABle OF Contents}

I. INTRODUCTION 2

II. INTERNATIONAL INVESTMENT LAW AND THE DEVELOPMENT

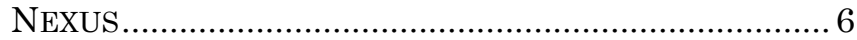

A. International Treaties and Initiatives .................... 7

B. International Investment Agreements .................. 8

C. International Investment Arbitrations ................ 11

III. IMPINGING ON HUMAN RIGHTS AND ENVIRONMENTAL ISSUES 13

A. Empirical Analysis ............................................... 13

B. A Textual Analysis ............................................... 17

1. The Right to Water ...................................... 17

2. The Right to Health.......................................20

3. Environmental Issues .................................25

IV. The TREatment of NONECONOMIC RIGHTS AT ODDS WITH

DEVELOPMENT IN INVESTMENT ARBITRATIONS ......... 33

V. THE LEgAL RELATIONSHIP BETWEEN INVESTMENT TREATIES AND NONECONOMIC ISSUES 36

\footnotetext{
* Professor of Law, University College London.
} 


\section{REFORMING INVESTMENT TREATIES TO BETTER INCORPORATE \\ DEVELOPMENT IDEALS ........................................... 39 \\ A. Substantive Reform ........................................... 40 \\ 1. The Right to Regulate ................................ 42 \\ 2. Fair and Equitable Treatment .................. 42 \\ 3. Safeguard Provisions.................................... 47 \\ 4. Investor Obligations ………........................50 \\ B. Procedural Reform ……………………….......... 53 \\ 1. Counterclaims.......................................... 53 \\ 2. Scientific Evidence ...................................... 54 \\ 3. Amicus and Independent Experts ..............55 \\ 4. Targeted Provisions..................................... 56 \\ 5. Reform of ISDS ……................................ 57}

VII. CONCLUSION............. 59

\section{INTRODUCTION}

It is widely acknowledged that the purpose of international investment treaties is to help promote and protect foreign investment. ${ }^{1}$ Yet this description may be incomplete since the protection to foreign investment afforded by these treaties is also a means of fostering a state's economic prosperity and economic development. ${ }^{2}$ Indeed, many investment treaties begin with the formal recognition of the role of foreign investment in seeking to improve economic development. ${ }^{3}$

Countless studies have shown that foreign investment is beneficial for economic development. ${ }^{4}$ This is because it can create employment, generate and disseminate knowledge and technology,

\footnotetext{
1 See, e.g., Siemens A.G. v. Argentina, ICSID Case No. ARB/02/8, Decision on Jurisdiction, 981 (Aug. 3, 2004); JESWALD W. SALACUSE, THE LAW OF INVESTMENT TREATIES 1 (2015); RUdOLF DOLZER \& CHRISTOPH SCHREUER, PRINCIPLES OF InTERNATIONAL INVESTMENT LAW, 67 (2d ed. 2012); Kenneth J. Vandevelde, Treaty Interpretation from a Negotiator's Perspective, 21 VAND. J. TRANSNAT'L L. 281, 299 n.61 (1989).

2 See Amco Asia Corp. v. Indonesia, ICSID Case No. ARB/81/1, Decision on Jurisdiction, ๆ 23 (Sept. 25, 1983); Joseph Charles Lemire v. Ukraine, ICSID Case No. ARB/06/18, Decision on Jurisdiction and Liability, Iף 272-73 (Jan. 14, 2010); Saluka Inv. BV v. Czech Republic, UNCITRAL Partial Award, ๆ 300 (Mar. 17, 2006). 3 See, e.g., Bilateral Investment Agreement for the Protection of Investments, Colom.-U.A.E., at pmbl., Nov. 12, 2017; Agreement on the Reciprocal Promotion and Protection of Investments, Guat.-Trin. \& Tobago, at pmbl., Aug. 13, 2013.

${ }^{4}$ See U.N. Conf. on Trade \& DeV., The ImpaCt of International InVEstment AGREEMENTS ON FOREIGN DIRECT INVESTMENT: AN OVERVIEW OF EMPIRICAL STUDIES 1998-2014 (2014) [hereinafter UNCTAD]; Anis Omria \& Bassem Kahouli, The Nexus Among Foreign Investment, Domestic Capital and Economic Growth: Empirical Evidence from the MENA Region, 68 RES. IN ECON. 257, 257 (2014); Cristina Jude \& Grégory Levieuge, Growth Effect of FDI in Developing Economies: The Role of Institutional Quality, 40 WoRLD ECON. 715, 715 (2017); Maha Kalai \& Nahed Zghidi, Foreign Direct Investment, Trade, and Economic Growth in MENA Countries: Empirical Analysis Using ARDL Bounds Testing Approach, 10 J. KNOWLEDGE ECON. 397, 398 (2017).
} 
and create spillover effects onto other industries. ${ }^{5}$ Moreover, it can assist "human capital formation, contribute to international trade integration, help create a more competitive business environment and enhance enterprise development." ${ }^{6}$ However, the economic benefits of foreign investment are not automatic. ${ }^{7}$ Rather, the magnitude of any benefit is dependent on the appropriate frameworks or policy tools the host state puts in place to realize these benefits. ${ }^{8}$

International investment agreements are an example of a framework or policy tool used to realize the benefits of economic development. In theory, these agreements are designed to attract the foreign investment necessary to begin paving the way to a country's economic development. However, countless studies have now proven the amorphous links between investment treaty conclusion and attraction of foreign investment. ${ }^{9}$ At the same time, investment protections found in these treaties may constrain a host state's ability to translate investment flows into benefits for the country. ${ }^{10}$ In particular, the provisions of investment treaties may thwart state efforts to regulate the effects of foreign investment in relation to social goals, such as those relating to human rights protection and the environment. ${ }^{11}$

Given the recognition of these problems, there has been a movement towards reestablishing international investment agreements as a vehicle for promoting sustainable development. ${ }^{12}$ Rather than merely an environmental concept as it was originally envisioned, sustainable development today encompasses concepts of economics, social, and environmental. ${ }^{13}$ Foreign investment,

5 See Org. For Econ. Cooperation \& Dev., Foreign Direct Investment for Development: MAXimising Benefits, Minimising Costs 9 (2002) [hereinafter OECD].

${ }^{6}$ Id.

7 See id. at 25.

8 See id.

9 See Mary Hallward-Driemeier, Do Bilateral Investment Treaties Attract FDI? Only a Bit and They Could Bite, in The EFfect of Treaties on Foreign Direct InVESTMENT: BILATERAL INVESTMENT TREATIES, DOUble TAXation TREATIES, AND InVESTMENT Flows 350 (Karl P. Sauvant \& Lisa E. Sachs eds., 2009); Christian Bellak, Economic Impact of Investment Agreements 20 (Vienna Univ. of Econ. and Bus., Dep't of Econ. Working Paper No. 200, 2015); Jennifer Tobin \& Susan RoseAckerman, Foreign Direct Investment and the Business Environment in Developing Countries: The Impact of Bilateral Investment Treaties 2 (Yale L. Sch., Ctr. for Law, Econ. \& Public Pol'y Res. Paper No. 293, 2005); UNCTAD, supra note 4, at 3.

10 See OECD, supra note 5, at 7.

11 But see id. at 172 (noting studies have shown foreign investment reduce poverty and improve social conditions and workers' rights).

12 Gro H. BRundtland, The Report of the World COMMission ON Environment AND DeVelopment: OuR Common Future 31 (1987) (defining sustainable development as "development that meets the needs of the present without compromising the ability of future generations to meet their own needs.").

13 See Anne van Aaken \& Tobias A. Lehmann, Sustainable Development and International Investment Law: An Harmonious View from Economics, in PROSPECTS 
seen through the lens of sustainable development, thus prizes investment that maximizes contributions to economic, social, and environmental development of host countries. ${ }^{14}$

Despite the equivocal evidence of foreign investment's positive contributions to social and environmental development, international organizations, such as the United Nations and the Organisation for Economic Co-operation and Development (OECD), are relying on private investors to meet the 2030 Sustainable Development Agenda. ${ }^{15}$ As UNCTAD has recently advised, governments should create a favourable and enabling investment environment and use international investment agreements (IIAs) to foster investment to meet sustainable development goals. ${ }^{16}$ However, in doing so, UNCTAD counsels, states should also ensure that they protect public interests by "safeguarding policy space for sustainable development." 17 States must therefore find a compromise between using IIAs to foster a favourable investment climate and ensuring that their use does notimpinge on policy space for protecting sustainable development goals.

This compromise is further complicated by the fact that, although IIAs are thought to be premised on a grand bargain-the protection of foreign investment in return for the promise of economic development ${ }^{18}$ _ both IIA agreements themselves, as well as their interpretation by investment arbitral tribunals, have tended not to respect this bargain. Rather, they have tended to focus primarily on protecting foreign investment, while giving little credence to promoting the economic development side of the bargain. ${ }^{19}$ Moreover, in myriad instances, arbitral tribunal interpretations of IIAs have also enabled foreign investors to impinge on states' policy space for protecting noneconomic issues. ${ }^{20}$ In other words, the foreign investment protection aspects of the treaties have been heralded, while the development aspects of them have not.

Yet what if the basic premise behind IIAs has been misconstrued? That is, that IIAs were constituted not to protect

In International InVestment LaW AND Policy 318 (Roberto Echandi \& Pierre Sauve eds., 2013); Tracey Strange \& Anne Bayley, Sustainable Development: LINKING ECONOMY, SOCIETY, ENVIRONMENT 25-27 (2005).

14 See Karl Sauvant \& Howard Mann, Strengthening the Global Trade and Investment System For Sustainable Development, 2 INT'L CTR. FOR TRADE \& SUSTAINABLE DEV. (2017).

15 See, e.g., United Nations Dev. Program, SDGF Framework of Engagement, https://www.sdgfund.org/sdgf-framework-engagement (last visited Jan. 15, 2020) [https://perma.cc/375Z-NAHD] (archived Jan. 15, 2020).

16 See UNCTAD Secretariat, Promoting Foreign Investment in the Sustainable Development Goals, U.N. Doc. TD/B/C.II/35, at 3 (Sept. 25, 2017).

17 Id. at 4 .

18 See Jeswald W. Salacuse \& Nicholas P. Sullivan, Do BITs Really Work: An Evaluation of Bilateral Investment Treaties and Their Grand Bargain, 6 HARV. INT'L L.J. 67, 77 (2005)

19 See infra Part II.B.

20 See id. 
foreign investment in exchange for economic development, but rather that the treaties were promulgated to protect foreign investment in order to promote economic development. This would argue in favour of a nexus between investment and development, which would suggest, at a minimum, two requirements for IIAs and their interpretation. First, IIAs must leave ample room for states to protect development goals; and second, due to the interrelated relationship between economic development, social well-being, and the environment, ${ }^{21}$ they must ensure that investors cannot impede social rights or environmental issues. In short, finding a nexus between investment and development would support the incorporation of sustainable development into international investment law.

This Article argues that not only does a nexus between investment and development exist, but that IIAs, and their interpretation by arbitral tribunals, do not consistently respect that relationship. As a result, IIAs are adversely affecting human rights and environmental issues and curtailing states' regulatory power in relation to these issues.

This argument will be made in six parts. Part II examines the nexus between international investment law and development, finding that the modern era of international investment law has repeatedly supported economic - and later sustainabledevelopment as an important component of IIAs.

Part III then turns to examine the implications of IIAs on development, focusing on human rights and environmental issues. Drawing from an empirical review of all publicly available investment arbitral awards, this Part locates fifty-six awards in which human rights and environmental issues are implicated. Owing to the small sample size, it then engages in a textual analysis of these awards to find that in many instances arbitral tribunals downplay or dismiss noneconomic issues leaving compromises to both human rights and environmental issues. Part IV examines whether these findings are problematic for development given that commentators have argued that such concerns are overstated.

Part V then looks to define the legal relationship between international investment law and noneconomic issues while Part VI examines methods by which states can reform IIAs to better account for development goals. This latter Part concludes that states must adopt both substantive and procedural reforms to IIAs to better account for sustainable development goals.

21 See G.A. Res. 64/236, at 2 (Mar. 31, 2010); Ulrich Beyerlin, Sustainable Development, in MAX Planck ENCYClopedia of PUblic InTERnational LAW 9 (2013). 


\section{INTERNATIONAL INVESTMENT LAW AND THE DEVELOPMENT NEXUS}

Historically, foreign investment has been an important objective for developed countries. In the late nineteenth and twentieth centuries, developed countries insured diplomatic claims of protection of their foreign investors' investment abroad with a threat of force, leading to the concept of gunboat diplomacy. ${ }^{22}$ PostWorld War II, developed countries established Treaties of Friendship, Commerce and Navigation to protect foreign investment, which, from the 1960s onward, evolved into bilateral investment treaties. ${ }^{23}$ These offered a more legalized form of protection for foreign investors. From the perspective of developed countries, these treaties would be used to "create a stable international legal framework to facilitate and protect" foreign investments. ${ }^{\mathbf{2 4}}$ Developed countries therefore viewed the foreign investment regime only through the lens of protecting foreign investment.

Developing countries, conversely, fought developed countries' efforts to establish hardline rules for the treatment of foreign investment, asserting their economic independence through the United Nations. In 1962, the General Assembly passed a resolution declaring that the right of people and nations "to permanent sovereignty over their natural wealth and resources" had to be "exercised in the interest of their national development and of the well-being of the people of the State concerned." ${ }^{25}$ Developing countries further sought to establish a new framework for international economic relations through the 1974 Declaration on the Establishment of a New International Economic Order. ${ }^{26}$ The new order was designed to "eliminate the widening gap between the developed and the developing countries and ensure steadily accelerating economic and social development and peace and justice for present and future generations." 27 While the developed countries rejected the new economic order, it became clear that the priority for developing countries in the international economic arena was the furtherance of their development.

Nevertheless, despite the developed countries' preference to focus on foreign investment protection, it was the notion of

\footnotetext{
22 See Taylor St. John, The Rise of Investor-State Arbitration: Politics, LaW, AND Unintended Consequences 53 (2018); Christopher K. Dalrymple, Politics and Foreign Investment: The Multilateral Investment Guarantee and the Calvo Clause, 29 CoRnell InT'L L. REv. 161, 164 (1996); Ibrahim F.I. Shihata, Towards a Greater Depoliticization of Investment Disputes, 1 ICSID REv. 1, 1-2 (1986).

23 See Andrew P. Newcombe \& Lluís Paradell, LaW and Practice of InVESTMent Treaties: Standards of TREATMent 22-23 (2009); SAlacuse, supra note 1 , at 2 .

24 SALACUSE, supra note 1 , at 125.

25 G.A. Res. 1803 (XVII), at 2, U.N. Doc. A/5344 (Dec. 14, 1962).

26 GA. Res. 3201 (S-VI), at pmbl., U.N. Doc. A/RES/S-6/3201 (May 1, 1974).

$27 \mathrm{Id}$.
} 
development that was used to shape the modern legal landscape for foreign investment. This can be seen in both economic-oriented and development-oriented international treaties and initiatives, international investment agreements, and international investment arbitrations.

\section{A. International Treaties and Initiatives}

Even though developed countries focused on protecting foreign investment, historically, it was development-and more specifically, the supposed links between foreign investment treaties and economic development ${ }^{28}$ - that characterized the rise of the modern legal framework of foreign investment protection. For instance, the Convention on the Settlement of Investment Disputes between States and Nationals of other States (ICSID Convention) ${ }^{29}$-in line with its association as an umbrella organization of the World Bank-made a concerted effort to tie foreign investment protection to the promotion of economic development. ${ }^{30}$ Its preamble thus reads: "the need for international cooperation for economic development, and the role of private international investment therein." 31 The executive directors of the ICSID Convention further stressed that the ICSID Convention "was prompted by the desire to strengthen the partnership between countries in the cause of economic development."32

The 1967 OECD Draft Convention on the Protection of Foreign Property also recognized "the importance of promoting the flow of capital for economic activity and development" and the "contribution which will be made towards this end by a clear statement of recognised principles relating to the protection of foreign property." 33 The 1985 Convention Establishing the Multilateral Investment Guarantee Agency (MIGA) similarly referenced economic development. ${ }^{34}$ The preamble to the MIGA thus noted the need "to strengthen international cooperation for economic development and to foster the contribution to such

28 See, e.g., UNCTAD, supra note 4 (summarizing a number of studies); Bellak, supra note 9 , at 2 (summarizing a number of studies); see also Muthucumaraswamy Sornarajah, Developing countries in the investment treaty system: A law for need or a law for greed?, in INTERNATIONAL INVESTMENT LAW AND DEVELOPMENT: BRIDGING THE GAP 46 (Stephan W. Schill et al. eds., 2016).

29 Convention on the Settlement of Investment Disputes between States and Nationals of Other States, Mar. 18, 1965, 4 I.L.M. 524. [hereinafter ICSID Convention].

30 See id. at art. 1; Sornarajah, supra note 28, at 53.

31 ICSID Convention, supra note 29, at pmbl.

32 See ICSID Convention, supra note 29 , at 40.

33 Org. For Econ. Cooperation \& Dev., Resolution of the Council on the Draft Convention on the Protection of Foreign Property, OECD Doc. OECD/LEGAL/0084, Annex (1967).

34 Convention Establishing the Multilateral Guarantee Agency, Oct. 11, 1985, 1508 U.N.T.S. 99. 
development of foreign investment in general and private foreign investment in particular."35

Alongside economic agreements, development agreements have equally recognized the links between investment and economic development. For example, Agenda 21 of the UN Conference on Environment and Development noted the importance of investment for countries' economic growth to meet sustainable development aims. ${ }^{36}$ Similarly, the Monterrey Consensus of the International Conference on Financing for Development noted the links between a stable investment climate and respect for property rights and the ability of business to operate with maximum development impact. ${ }^{37}$ The Johannesburg Declaration on Sustainable Development further observed the opportunities for sustainable development that investment flows opened up, ${ }^{38}$ while the Doha Declaration on Financing for Development specifically recognized that foreign direct investment is a vital complement to development efforts. ${ }^{39}$ More recently, the Addis Ababa Action Agenda noted the important contribution that foreign investment can make to sustainable development, ${ }^{40}$ while the idea of investment is replete throughout the United Nation's Sustainable Development Agenda 2030. ${ }^{41}$

\section{B. International Investment Agreements}

International investment agreements, themselves, have also stressed the importance of economic development. Thus, the first bilateral investment treaty (BIT) concluded by Germany and Pakistan recognized that the treaty represented an "understanding" between the two countries that would promote investment and "increase the prosperity of both" countries. ${ }^{42}$ Subsequent treaties have gone on to reference the importance of economic development in the text of the treaty. ${ }^{43}$ Even former

35 Id. at pmbl.

36 See U.N. Conference on Environment and Development Agenda 21, ๆ 2.23, June, 1992, U.N. Doc. A/CONF.151/26/Rev. I/Vol. I.

37 See Monterrey Consensus of the International Conference on Financing for Development, ๆ 21, Mar. 22, 2002, U.N. Doc. A/AC.257/32.

38 See Report of the World Summit on Sustainable Development, ๆ 14, U.N. Doc. A/CONF.199/20 (2002).

39 See Doha Declaration on Financing for Development, ๆ 23, Dec. 9, 2008, U.N. Doc. A/CONF.212/L.1/Rev.1 .

40 See Third International Conference on Financing for Development, $\uparrow 45$, July 15, 2015, U.N. Doc. A/Conf.227/L.1.

41 See GA Res. 70/1, ๆๆ Goal 2.a, Goal 10.b, 67 (Sept. 25, 2015).

42 See Convention Concerning the Encouragement of Capital Investment and the Protection of Property, Belg.-Tunis., pmbl., July 15, 1964 (noting how "the contractual protection of investments is likely to . . . increase prosperity."); Agreement on the Encouragement and Reciprocal Protection of Investments, Ger.Pak., pmbl., Nov. 25, 1959.

43 See, e.g. Agreement on the Reciprocal Encouragement and Protection of Investments, pmbl., Alg.-Jordan, Aug. 1, 1996; Treaty Concerning the Encouragement and Reciprocal Protection of Investment Russ.-U.S., pmbl., June 
President Ronald Reagan noted that US policy toward international investment had concluded that the international investment system "provides the best and most efficient mechanism to promote global economic development." 44

Building on the idea of the importance of economic development, some free trade and investment treaties have also enveloped goals of sustainable development within their ambit. For instance, the North American Free Trade Agreement (NAFTA) and the Comprehensive and Progressive Agreement for Trans-Pacific Partnership (CPTPP) both reference sustainable development or sustainable growth in their preambles. ${ }^{45}$ Indeed, the NAFTA and the CPTPP, in addition to the Dominican Republic-Central America Free Trade Agreement, refer to several development goals in their preambles, including creating new opportunities for economic and social development, improving working conditions and living standards, enhancing workers' rights, bringing economic growth and social benefits, and reducing poverty. ${ }^{46}$ The European Free Trade Association (EFTA)-Bosnia and Herzegovina free trade agreement goes further by incorporating sustainable development into several elements of the treaty. It, thus, includes sustainable development as one of the primary objectives of the treaty (alongside prosperity) and creates a separate obligation for its state parties to promote the agreement's economic elements in a manner that contributes to sustainable development. ${ }^{47}$

Several modern bilateral investment treaties include notions of sustainable development within their ambit as well. ${ }^{48}$ Tellingly, several treaties even specify the causal relationship between investment and sustainable development. ${ }^{49}$ For instance, the 2017

17, 1992; Agreement on the Reciprocal Promotion and Protection of Investments, Switz.-Uru., pmbl., Oct. 7, 1988; Agreement Concerning the Reciprocal Encouragement and Protection of Investments, Fr.-Malta, pmbl., Aug. 11, 1976; Agreement Between the Government of France and The Republic of Tunisia Concerning the Reciprocal Encouragement and Protection of Investments, Fr.Tunis., pmbl., 1963.

44 Letter of Transmittal 71-118 from Ronald Regan, President of the United States, to U.S. Senate (Mar. 25, 1986).

45 North American Free Trade Agreement, U.S.-Can.-Mex., pmbl., Dec. 17, 1992, 32 I.L.M. 289 (1993) [hereinafter NAFTA]; Comprehensive and Progressive Agreement for Trans-Pacific Partnership, Mar. 8, 2018 [hereinafter CPTPP].

46 See id.; Dom. Rep.-Central America Free Trade Agreement, § 2, Aug. 5, 2004, 119 Stat. 462 [hereinafter DR-CAFTA].

47 See Free Trade Agreement, European Free Trade Ass'n-Bosn. \& Herz. §§ pmbl., art. 1, 33, June 24, 2013 [hereinafter EFTA-Bosn. \& Herz. Agreement].

48 See, e.g., Agreement on Investment Protection, E.U.-Sing., pmbl., Apr. 4, 2018; Agreement for the Promotion and Reciprocal Protection of Investments, Arg.U.A.E., pmbl., Apr. 16, 2018; Agreement on the Promotion and Reciprocal Protection of Investments, Can.-Burk. Faso, pmbl., Apr. 20, 2015.

49 See, e.g., Bilateral Investment Treaty, Belr.-India, pmbl., Sept. 24, 2018 [hereinafter Belarus-India BIT]; Agreement on the Promotion and Reciprocal Protection of Investments, Switz.-Egypt, pmbl., June 7, 2010; Agreement for the Promotion and Reciprocal Protection of Investment, Austria-Kaz., pmbl., January 12, 2010; Agreement for the Promotion and Reciprocal Protection of Investment 
Slovakia-Iran BIT specifies that "investment is critical for sustainable development" and that the parties are "seeking to promote investment that contributes to the sustainable development." 50 The 2016 Morocco-Nigeria BIT elaborates on this relationship by recognizing the "contribution investment can make to the sustainable development of the state parties, including the reduction of poverty, increase of productive capacity, economic growth, the transfer of technology, and the furtherance of human rights and human development." 51

Yet beyond these references to sustainable development, primarily only in treaty preambles, some BITs now also impose specific responsibilities on the investor vis-à-vis sustainable development. For instance, some BITs define the term "investment" in terms of its contribution to sustainable development, suggesting that an investment's failure to contribute to a country's sustainable development would render it beyond the scope of the BIT. ${ }^{52}$ Other treaties note that investors should "strive to achieve the highest possible level of contribution to the sustainable development of the Host State" by endeavouring to contribute to "economic, social and environmental progress, aiming at achieving sustainable development." 53

Model BITs, which often provide the framework for future treaties, further echo the importance of the links between foreign investment and sustainable development. The Dutch Model BIT, for instance, obliges state parties to promote foreign investment "in such a way as to contribute to the objective of sustainable development." 54 Similarly, India's Model BIT both aligns investment with sustainable development, ${ }^{55}$ but also requires investors to strive to contribute to host state development objectives ${ }^{56}$ a requirement enforceable by the host state. ${ }^{57}$

Japan-Papua N.G. pmbl., Apr. 26, 2011; Agreement for the Promotion and Reciprocal Protection of Investments, Rwanda-U.A.E., pmbl., July 11, 2017.

50 Agreement or the Promotion and Reciprocal Protection of Investment, Slovk.Iran, pmbl., Jan. 19, 2016 [hereinafter Slovakia-Iran BIT].

51 Reciprocal Investment Promotion and Protection Agreement, Morocco-Nigeria pmbl., Dec., 3, 2016 [hereinafter Morocco-Nigeria BIT].

52 See, e.g., Belarus-India BIT, supra note 49, at art. 1.4; Slovakia-Iran BIT, supra note 50, at art. 1.2; Morocco-Nigeria BIT, supra note 51, at art. 1.

53 Agreement on Investment Cooperation and Facilitation Braz.-Surin., art. 15.1, 15.2, May 2, 2018; see also Agreement on Investment Cooperation and Facilitation Braz.-Malawi, art. 9, 2015; Morocco-Nigeria BIT, supra note 51, at art. 24 (noting "investors and their investments should strive to make the maximum feasible contributions to the sustainable development of the Host State and local community ....”).

54 Agreement on Reciprocal Promotion and Protection of Investments (Netherlands Draft Model BIT), art. 6, 2018.

55 See Model Text for the Indian Bilateral Investment Treaty, pmbl., Dec. 2015, https://www.mygov.in/sites/default/files/master_image/Model\%20Text\%20for\%20th e\%20Indian\%20Bilateral\%20Investment\%20Treaty.pdf

[https://perma.cc/ZT59-NYQ8] (archived Oct. 25, 2019) [hereinafter India Model BIT].

56 See id. at art. 12.2.

57 See id. at art. 8.4. 
In addition to referencing sustainable development, some IIAs also break the concept down and reference its constituent elements, for instance, through references to human rights and environmental protection. ${ }^{58} \mathrm{~A}$ number of treaties, for instance, refer to the importance of human rights, labour, or the environment in their preambles ${ }^{59}$ or require states not to lower human rights, labour, or environmental protection standards in order to encourage foreign investment. ${ }^{60}$ However, some treaties delineate more extensive obligations for states in these areas. Thus, the EFTA-Bosnia FTA requires its state parties to strive to facilitate and promote foreign investment beneficial to the environment, including environmental technologies and sustainable renewable energy. ${ }^{61}$

\section{International Investment Arbitrations}

Beyond treaties and international initiatives, several arbitral tribunals have specifically recognized the importance of development in the investment context. For instance, in Joseph Charles Lemire v. Ukraine, the tribunal observed that the object and purpose of the IIA in question was "not to protect foreign investments per se, but as an aid to the development of the domestic economy." ${ }^{2}$ Similarly, the tribunal in AWG Group noted that in treaties, which promote economic development or economic prosperity, the protection and promotion of foreign investment "are only a means to that end." 63

Some tribunals have even defined the concept of investment in terms of a project's contribution to economic development. The Salini tribunal, for instance, held that "investment infers . . . contribution to the economic development of the host State." 64

58 On human rights and the environment as elements of sustainable development, see, e.g., Agreement for the Promotion and Protection of Investment, AustriaNigeria, pmbl., Apr. 8, 2013 [hereinafter Austria-Nigeria BIT] (noting "investment agreements and multilateral agreements on the protection environment, human rights or labour rights are meant to foster global sustainable development"); Association Agreement, EU-Geor., pmbl., June 16, 2014 (noting that the states "aim to improve the protection of human health as an essential element for sustainable development and economic growth").

59 See EFTA-Bosn. \& Herz. Agreement, supra note 47, at pmbl.; Austria-Nigeria BIT, supra note 58 , at pmbl.

60 See Investment Agreement, China-Chile, art. 15, Nov. 18, 2016; Investment Protection and Promotion Agreement, Can.-Côte d'Ivoire, art. 15, Nov. 30, 2014; NAFTA, supra note 45, at ch. 11; Morocco-Nigeria BIT, supra note 51, at art. 15; Austria-Nigeria BIT, supra note 58, at art. 4-5.

61 See EFTA-Bosn. \& Herz. Agreement, supra note 47, at art. 39.

62 Joseph Charles Lemire v. Ukraine, ICSID Case No. ARB/06/18 at ๆฯ 271-73.

63 AWG Grp. Ltd. v. Argentina, ICSID Case No. ARB/03/19, Decision on Liability, ๆ 218 (July 30, 2010),

64 Salini Costruttori SpA \& Italstrade SpA v. Morocco, ICSID Case No. ARB/00/4, Decision on Jurisdiction, ๆ 52 (July 23, 2001). See also CSOB v. Slovakia, ICSID Case No. ARB/97/4, Decision of the Tribunal on Objections to Jurisdiction, ๆ 64 (May 
While few tribunals have adopted the Salini rationale as a strict criteria for defining an investment, ${ }^{65}$ some tribunals have been willing to consider a project's contribution to a country's economic development in their overall analysis of whether it constitutes an investment. ${ }^{66}$ Moreover, for financial-as opposed to physicalinvestments tribunals have been more willing to consider their effects on economic development, noting that such investments should provide a benefit to the host state and support the host state's economic development. ${ }^{67}$

Despite tribunal reluctance to consider economic development as a strict element of an investment, several tribunals have confirmed the relationship between foreign investment and economic developments. As they have observed, economic development is an "expected consequence" 68 or the objective ${ }^{69}$ of an investment. Moreover, they have concluded that, in aggregate, the activity of foreign investment should contribute to a host state's economic development. 70 In other words, even if arbitral jurisprudence does not suggest that economic development is a

24, 1999); Malaysian Historical Salvors, SDN, BHD v. Malaysia, ICSID Case No. ARB/05/10, Award on Jurisdiction, If 123 (May 17, 2007); Malaysian Historical Salvors, SDN, BHD v. Malaysia, ICSID Case No. ARB/05/10, Decision on the Application for Annulment, I 3 (Apr. 16, 2009) (dissenting opinion of Judge Shahabuddeen); Patrick Mitchell v. Democratic Republic of Congo, ICSID Case No. ARB/99/7, Decision on the Application for Annulment of the Award, I 31 (Nov. 1, 2006).

65 See, e.g., Alps Fin. v. Slovakia., UNCITRAL Preliminary Redacted Version of the Award, (Mar. 25, 2011); GEA Grp. v. Ukraine, ICSID Case No. ARB/08/16, Award, If 314 (Mar. 31, 2011); L.E.S.I. S.p.A. \& Astaldi S.p.A. v. Algeria, ICSID Case No. ARB/05/03, Decision on Jurisdiction, If 72 (July 12, 2006); Gavazzi \& Gavazzi v. Romania, Decision on Jurisdiction, Admissibility And Liability, ICSID Case No. $\mathrm{ARB} / 12 / 25$, I 114 (Apr. 21, 2015); Romak v. Uzbekistan., PCA Case No. AA280, Award, ๆ 200 (Nov. 26, 2009); Fakes v. Turkey, ICSID Case No. ARB/07/20, Award, ब 110-11 (July 14, 2010); Casado \& Pres. Allende Found. v. Chile, ICSID Case No. $\mathrm{ARB} / 98 / 02$, ๆ 232 (May 8, 2008).

66 See, e.g., Bayindir Insaat Turizm Ticaret Ve Sanayi A.S. v. Pakistan, ICSID Case No. ARB/03/29, Decision on Jurisdiction, 137 (Nov. 14, 2005); Biwater Gauff Ltd. v. Tanzania, ICSID Case No. ARB/05/22, Award, ๆ 316 (July 24, 2008); Consortium Groupement L.E.S.I.-DIPENTA v. Algeria, ICSID Case No. ARB/03/08, Award, ๆ 13(iv) (Jan. 10, 2005); Inmaris Perestroika Sailing Mar. Serv. Gmbh v. Ukraine, ICSID Case No. ARB/08/8, Decision on Jurisdiction, 132 (Mar. 8, 2010); Phoenix Action Ltd. v. Czech Republic, ICSID Case No. ARB/06/5, Award, I 115 (Apr. 15, 2009); see also Deutsche Bank AG v. Sri Lanka, ICSID Case No. ARB/09/02, ๆ 48 (Oct. 23, 2012) (dissenting opinion of Judge Khan).

67 See, e.g., Abaclat v. Argentina, ICSID Case No. ARB/07/5, Decision on Jurisdiction and Admissibility, 374 (Aug. 4, 2011). But see Nova Scotia Power Inc. v. Venezuela, ICSID Case No. ARB(AF)/11/1, Excerpts of Award, If 130 (Apr. 30, 2014) (noting a benefit need not amount to economic development, although "a further enquiry regarding economic development may be appropriate.").

68 Casado v. Chile, supra note 65, at $\uparrow$ 232; Quiborax \& NonMetallic Minerals v. Bolivia, ICSID Case No ARB/06/2, Award, I 222 (Sept. 16, 2015) [hereinafter Quiborax v. Bolivia].

69 See Capital Fin. Holdings Luxembourg S.A. v. Cameroon, ICSID Case No. $\mathrm{ARB} / 15 / 18$, Award, ๆ 422 (June 22, 2017).

70 See İçkale İnşaat Ltd. Şirketi v. Turkmenistan., ICSID Case No. ARB/10/24, Award, ๆ 291 (Mar. 8, 2016). 
criterion for investment, it suggests a relationship between investment and economic development.

Therefore, from the references to economic development in some of the founding documents of international investment law and in treaties and in arbitral case law, it seems apparent that there is a nexus between international investment law and development. Yet, for the most part, neither economic development nor sustainable development concerns inform either the substantive rules on investment protection or the interpretation of these rules. Instead, both investment rules and their interpretation have tended to focus on investor's property protection rights.

\section{IMPINGING ON HUMAN RightS AND ENVIRONMENTAL ISSUES}

Having located a nexus between foreign investment and economic, or sustainable, development, gives further credence to the argument that foreign investment should contribute to economic or sustainable development. Indeed, at a minimum the nexus between foreign investment and economic or sustainable development suggests that foreign investment should not impinge on a state's development goals. To be sure, a state's development goals may be myriad, but at their core they must ensure that they enable individuals to enjoy their human rights. ${ }^{71}$ Moreover, this will also implicate environmental issues insofar as there is a human right to a healthy environment as well as through the close links between human and environmental rights. ${ }^{72}$

A review of investment arbitration cases confirms that there have been a number of instances where human rights or environmental issues have been implicated in foreign investment matters, which have not consistently promoted a state's development goals. This can be seen from a brief empirical analysis of such awards as well as by reviewing the text of the awards themselves.

\section{A. Empirical Analysis}

\footnotetext{
71 For arguments on the links between economic development and human rights, see A.H. ROBERTson \& J.G. MERRILS, Human Rights IN THE WORLD: AN InTRODUCTION TO THE STUdy OF THE INTERNATIONAL PROTECTION OF HUMAN Rights 14-15 (1996); JACK DONNELly, UNIVERSAL HuMAN RIGHTS IN THEORY AND PraCtice 234 (3d ed., 2013); World BANK, DeVElopment and Human Rights: The ROLE OF THE WORLD BANK vii (1998); Dominic McGoldrick, Sustainable Development and Human Rights: An Integrated Conception, 45 INT'L \& COMP. L.Q. 796, 796-97 (1996).

72 See generally The Human Right to a Healthy Environment (John Knox \& Ramin Pejan eds., 2018).
} 
Drawing from all publicly ${ }^{73}$ available investment arbitration awards, a review of these cases located fifty-six arbitral awards in which human rights or environmental issues were implicated. ${ }^{74} \mathrm{An}$ award was characterized as involving a human rights or environmental issue if the state or amicus curiae argued that such an issue was present in the dispute. ${ }^{75}$ Awards were selected from scholarly literature and discussion as well as through keyword searches of "human rights" and "environment," along with mapping features, on two investment law databases. ${ }^{76}$ Since the aim was to determine whether IIAs were infringing on a state's development, the review did not focus on human rights or environmental complaints raised by investors ${ }^{77}$ nor on awards at the jurisdiction stage in which the noneconomic issue was peripheral. ${ }^{78}$ The cutoff date for the reviews was December 2018, and the reviewed awards spanned between 1992 and 2018. ${ }^{79}$

Although the small sample size does not support the drawing of determinative conclusions, it may suggest trends in this area. For instance, the surveyed cases suggested that human rights or environmental issues were, from the state's perspective, implicated in a number of different areas. These included: the right to water, the right to health, the right to a healthy environment,

73 Not all investment arbitral awards are made public. Consequently, the reviewed cases likely do not represent the entirety of investment arbitral awards dealing with human rights or environmental issues. See infra Appendix 1.

74 This does not include those cases involving human rights/environmental issues that were settled or discontinued. See infra Appendix 1.

75 This excluded cases in which the background of the case may have involved a human rights or environmental issue but the subject matter of the arbitration involved other grounds. For instance, Chevron v. Ecuador, PCA Case No. 2009-23 (2012) was not included in the review, despite initially raising environmental issues, as the subject matter of the arbitration focused on the investor's treatment in the Ecuadorian judicial/administrative processes. Similarly, arbitrations involving state regulatory changes for reasons other than human rights or environmental reasons were excluded. For this reason, the Energy Charter treaty arbitrations against Spain, and other countries, were excluded despite alternative energy projects being an environmental issue.

76 These included Investment Arbitration Reporter and Investor State Law Guide. To limit selection bias, an award selected from one method was doubled checked against the other to confirm it involved a human rights or environmental issue.

77 See Daniel Behn \& Malcolm Langford, Trumping the Environment? An Empirical Perspective on the Legitimacy of Investment Treaty Arbitration, 18 J. WORLD INV. \& TRADE 14, 15 (2017) (discussing environmental awards involving investors); Silvia Steininger, What's Human Rights Got To Do With It? An Empirical Analysis of Human Rights References in Investment Arbitration, 31 LEIDEN J. INT'L L. 33, 42 (2018) (discussing human rights awards involving investors).

78 For instance, awards dealing with environmental issues which were dismissed at the jurisdiction stage for reasons unconnected to the environmental issues were not considered. See, e.g., Commerce Grp. Corp. \& San Sebastian Gold Mines, Inc. v. El Salvador, ICSID Case No. ARB/09/17, Award, I 115 (Mar. 14, 2011); Corona Materials LLC v. Dominican Republic, ICSID Case No. ARB(AF)/14/3, Award, ๆ 270 (31 May 2016); Renco Grp., Inc. v. Peru, Partial Award on Jurisdiction, ICSID Case No. UNCT/13/1, Award, ๆ 152 (15 July 2016).

79 See infra Appendix 1 for the data set. 
environmental issues, indigenous rights, the right to culture, and social issues stemming from an economic crisis. ${ }^{80}$

Tribunals tended to treat these issues in a number of different ways. In the surveyed cases, the most common treatment by tribunals was to acknowledge the noneconomic issue before disregarding or discounting it in its analysis. ${ }^{81}$ Several tribunals also disregarded the issue entirely, almost from the outset, ${ }^{82}$ or sidestepped it by focusing its analysis on other issues, in some cases deliberately. ${ }^{83}$ However, in a sign of potential promise, almost one out of every five tribunals explicitly engaged with the noneconomic issues in its analysis; that is, the tribunal specifically acknowledged the noneconomic right in question and then included the right in its legal analysis. ${ }^{84}$ While this did not necessarily always translate into absolving the state of all liability, it tended to contribute to a reduction of damages imposed on the state for breaches of its obligations. 85 Tribunal engagement with noneconomic issues also tended to be greater where a health issue

80 The awards are characterized by the nature of non-economic right in Appendix 1. See infra Appendix 1.

81 See, e.g., SAUR Int'l S.A. v. Argentina, ICSID Case No ARB/04/4, Decision on Jurisdiction and Liability, 330 (June 6, 2012) (acknowledging the state's right to protect human rights but noting that such protection must be combined with respect for investor rights); Suez, Sociedad General de Aguas de Barcelona S.A. v. Argentina, ICSID Case No. ARB/03/19, Decision on Jurisdiction, ๆ 51 (Aug. 3, 2006) [hereinafter Suez v. Argentina]; Suez, Sociedad General de Aguas de Barcelona S.A. v. Argentina, ICSID Case No. ARB/03/17, Decision on Jurisdiction, ๆ 262 (May 16, 2006) (noting that Argentina is subject to human rights obligation but finding that those obligations are not inconsistent with its investment treaty obligations).

82 See, e.g., Azurix Corp. v. Argentina, ICSID Case No ARB/01/12, Award, I 261 (July 14, 2006) (the matter of human rights "has not been fully argued and the Tribunal fails to understand the incompatibility in the specifics of the instant case); CMS Gas Transmission Co. v. Argentina, ICSID Case No. ARB/01/8, Award, ๆ 121 (May 12, 2005) [hereinafter CMS v. Argentina] (noting there is no question of affecting fundamental human rights when considering the issues disputed by the parties).

83 See, e.g., Glamis Gold, Ltd. v. United States, UNCITRAL Award, ๆ 8 (June 8, 2009) ("...the decision in this proceeding has been awaited by . . . entities concerned with environmental regulation [and] indigenous peoples ... These issues were extensively argued in this case and considered by the Tribunal. However, given the Tribunal's holdings, the Tribunal is not required to decided many of [these] issues . ...").

84 See, e.g., Al Tamimi v. Oman, ICSID Case No. ARB/11/33, Award, ๆ 448 (Nov. 3, 2015); Cortec Mining Kenya v. Kenya, ICSID Case No. ARB/15/29, Award, ๆ 395 96 (Oct. 22, 2018); Aven v. Costa Rica, ICSID Case No. UNCT/15/3, Award, ๆ 762 (Sept. 18, 2018); Parkerings-Compagniet AS v. Lithuania, ICSID Case No. ARB/05/8, Award, I 465 (Sept. 11, 2007); Philip Morris Brands Sàrl v. Uruguay, ICSID Case No. ARB/10/7, Award, ๆ 129 (July 8, 2016) [hereinafter Philip Morris v. Uruguay]; Urbaser S.A. v. Argentina, ICSID Case No. ARB/07/26, Award, II 325 (Dec. 8, 2016). See also infra Part II.B.

85 Compare Cont'l Cas. Co. v. Argentina, ICSID Case No. ARB/03/9, Award, ๆ 320 (Sept. 5, 2008) (recognizing the social issues Argentina faced stemming from its economic crisis of USD 2.8 million), with Nat'l Grid PLC v. Argentina, UNCITRAL Award, I 390 (Nov. 3, 2008) (failing to recognize social issues stemming from economic crisis and awarded USD 54 million). 
was involved, ${ }^{86}$ in more recent disputes, ${ }^{87}$ or where the state filed a counterclaim alleging that the investor had breached a human right or environmental obligation. ${ }^{88}$

From the surveyed cases, the most common alleged breaches of the investment treaty related to fair and equitable treatment (FET) and expropriation. In just under two-thirds of the examined cases, the tribunals found a violation of either or both of these obligations. ${ }^{89} \mathrm{FET}$ was, however, the more successful basis for a claim as more than half the awards involved a finding of a breach of FET, while tribunals found an expropriation in just under 30 percent of the awards. ${ }^{90}$

Damage awards in these cases were also often significant, ranging from USD $\$ 2.1$ million to $\$ 1.2$ billion. ${ }^{91} \mathrm{In}$ addition, human rights or environmental issues in investment disputes weighed more heavily on developing, rather than developed or emerging economies. The vast proportion of the cases were instigated against a developing economy country with Argentina being the most frequent defendant state. ${ }^{92}$ However, several cases were also brought against developed economies with Canada being the most frequent defendant in this group. ${ }^{93}$

Much commentary has been devoted to the identity characteristics of arbitrators. ${ }^{94}$ However, from the small number of surveyed cases, there was no indication that a particular identity group seemed to be more prone to taking into account human rights or environmental issues into their analysis. ${ }^{95}$ Nevertheless,

86 See the discussion in infra Part II.B.2.

87 See, e.g., Aven v. Costa Rica, supra note 84, at 9 39; Cortec v. Kenya, supra note 84, at 98 ; Philip Morris v. Uruguay, supra note 84, at 56; Urbaser v. Argentina, supra note 84 , at 92.

88 See, e.g., Aven v. Costa Rica, supra note 83, at 9 8; Burlington Res. Inc. v. Ecuador, ICSID Case No. ARB/08/5, Decision on Counterclaims, ๆ 52 (Feb. 7, 2017); Perenco v. Ecuador, ICSID Case No. ARB/08/6, Interim Decision On The Environmental Counterclaim, I 34 (Aug. 11, 2015); Urbaser v. Argentina, supra note 83 , at 115 .

89 Thirty-five out of fifty-six awards involved a finding of a breach of fair and equitable treatment or expropriation or both. See infra Appendix 1 for the awards.

90 Twenty-nine out of fifty-six cases involved a finding of a breach of FET while sixteen out of fifty-six awards found a breach of expropriation. See infra Appendix 1 for the awards.

91 See infra Appendix 1 for a list of damages awarded in each surveyed arbitration.

92 Forty-one out of fifty-six cases were against a developing country: Barbados, Argentina, Tanzania, Uruguay, El Salvador, Costa Rica, Mexico, Ecuador, Venezuela, Kenya, Zimbabwe, Peru, Egypt, Chile, and Mongolia. See infra Appendix 1.

93 Canada was the defendant in one-quarter of all the cases brought against developed countries. See infra Appendix 1.

94 See Susan D. Franck et al., The Diversity Challenge: Exploring the "Invisible College" of International Arbitration, 53 Colum. J. TRANSNAT'L L. 429, 429 (2015); Gus van Harten, Leaders in the Expansive and Restrictive Interpretation of Investment Treaties: A Descriptive Study of ISDS Awards to 2010, 29 EUR. J. INT'L L. 507, 509 (2018).

95 It is difficult to conclusively determine the influence of female arbitrators or developing economy arbitrators given the small sample size. There were only three female arbitrators in the 56 awards reviewed and approximately one-third of the 
arbitrators with a background as a university professor ${ }^{96}$ or as a judge ${ }^{97}$ appeared to give more credence to human rights or environmental issues than arbitrators with a strictly commercial background.

\section{B. A Textual Analysis}

While the empirical examination of the awards was limited by its small sample size, many of the trends the review suggests are supported by a deeper examination into the awards themselves. Indeed, a closer look at some of these arbitral disputes confirms the impact of IIAs on noneconomic rights as well as, in some cases, the tribunal's dismissive attitude or reluctance towards dealing with such issues. These can be discerned from a review of cases involving the right to water, the right to health, and environmental issues.

\section{The Right to Water}

As early as 2007, the United Nations (UN) recognized the human rights implications of international investment treaties relating to the right to water. At that time, the UN Commissioner on Human Rights noted that current investor-state disputes between private water companies

\footnotetext{
draw attention to the potential impact that obligations arising from bilateral investment treaties can have on the duty of States to regulate companies in the context of private provision of water or sanitation services. It remains unclear whether and how the obligations of Governments under international human rights instruments will be taken into account [in these contexts].98
}

After seven water-related investment disputes, ${ }^{99}$ the UN Commissioner's concerns remain, since in most instances tribunals

arbitrators came from a developing economy country. However, the awards in which tribunals thoroughly engaged with human rights or environmental issues were not composed of more women or developing economy arbitrators. See infra Appendix 1.

96 See, e.g., Philip Morris v. Uruguay, supra note 84, at 1 18; Urbaser v. Argentina, supra note 84, at 9 9; Aven v. Costa Rica, supra note 84, at 939.

97 See, e.g., Cont'l Cas. Co. v. Argentina, ICSID Case No. ARB/03/9, Award, ๆ 11 (Sept. 5, 2008); Parkerings-Compagniet AS v. Lithuania, ICSID Case No. ARB/05/8, Award, ๆ 17 (Sept. 11, 2007); Aven v. Costa Rica, supra note 84, at 93.

98 U.N. Human Rights Council, Report of the United Nations High Commissioner for Human Rights on the scope and content of the relevant human rights obligations related to equitable access to safe drinking water and sanitation under international human rights instruments, U.N. Doc. A/HRC/6/3, ๆ 63 (Aug. 16, 2007).

99 See Biwater Gauff Ltd. v. Tanzania, ICSID Case No. ARB/05/22, Award, q 33 (July 24, 2008); Compañiá de Aguas del Aconquija S.A. v. Argentina, ICSID Case No. ARB/97/3, Award, ๆ 1.1 (Aug. 20, 2007); Impregilo SpA v. Argentina, ICSID Case No. ARB/07/17, Award, I 1 (June 21, 2011); SAUR Int'l S.A. v. Argentina, ICSID Case No ARB/04/4, Decision on Jurisdiction and Liability (June 6, 2012); Suez, Sociedad General de Aguas de Barcelona S.A. v. Argentina, ICSID Case No. ARB/03/17, Decision on Jurisdiction, I 1 (July 30, 2010); Azurix Corp. v. Argentina, supra note 82, at 939 ; Urbaser v. Argentina, supra note 84, at 93. 
have failed to effectively engage with the right to water when pitted against an investor's rights. In part, tribunal reluctance to engage with right-to-water issues may be because, as one tribunal suggested, the state did not "fully argue" the human rights at issue. ${ }^{100}$ Although in another case, where the state argued that its actions were driven by the need to guarantee its inhabitants the human right to water, the tribunal still ignored the issue entirely. ${ }^{101}$

Even in disputes in which both states and amici curiae extensively elaborated on the right to water, there has been little integration of human rights issues into tribunal analysis. Thus, in Biwater v. Tanzania, amici curiae contended that investor responsibility had to be "assessed in the context of sustainable development and human rights." 102 While the tribunal noted that the amici's observations were "useful" and would be used to inform their analysis, ${ }^{103}$ their written reasoning failed to make any explicit mention of any of the arguments raised by the amici.

Similarly, in the Suez v. Argentina arbitrations, Argentina argued in both disputes that the tribunal's determination of breach of any treaty provisions should be contextualized and informed by the right to water. ${ }^{104}$ These arguments were supported in one of the arbitrations by amici curiae who argued that the right to water was linked to other human rights, such as the right to human health, and that human rights obligations required Argentina to take measures "to ensure access to water by the population, including physical and economic access." 105

Despite these arguments, the tribunal concluded that Argentina's human rights obligations neither superseded its investment treaty obligations nor gave it the authority to take actions in contravention of its investment treaty obligations. 106 Instead, it held that Argentina was subject to both its human rights and investment treaty obligations, that these obligations were "not inconsistent, contradictory, or mutually exclusive" and that Argentina should have respected both sets of obligations. ${ }^{107}$ Thus, although the tribunal recognized Argentina's human rights obligations, it did not use this recognition to integrate these rights into its analysis.

Tribunal acknowledgement of the relevant human rights before discounting its relevance is also apparent in SAUR $v$.

\footnotetext{
100 Azurix Corp. v. Argentina, supra note 82, at 9261.

101 Impregilo v. Argentina, supra note 100, at $\uparrow 228$.

102 Biwater Gauff v. Tanzania, supra note 100, at 9 ๆ 379, 387.

103 Id. at 392.

104 See Suez, Sociedad General de Aguas de Barcelona S.A. v. Argentina, ICSID Case No. ARB/03/17, Decision on Liability, ๆ 232 (July 30, 2010) [ARB/03/17]; Suez, Sociedad General de Aguas de Barcelona S.A. and Interagua Servicios Integrales de Agua S.A. v. Argentina, ICSID Case No. ARB/03/19, Decision on Liability, I 252 (July 30, 2010) [hereinafter ARB/03/19].

$105 \mathrm{ARB} / 03 / 19$, supra note 105 , at 256

106 See ARB/03/17, supra note 105, at 9 240; ARB/03/19, supra note 105, at ๆ 262.

$107 \mathrm{ARB} / 03 / 17$, supra note 105, at $\uparrow 240 ; \mathrm{ARB} / 03 / 19$, supra note 105, at 262.
} 
Argentina. ${ }^{108}$ In that dispute, Argentina argued that its investment treaty obligations should be read in harmony with its human rights obligations, in particular the right to water. ${ }^{109}$ The tribunal agreed in part, finding that human rights, and the right to water in particular, were part of the various sources it should take into account in resolving this dispute. ${ }^{110}$ However, it found that the state's right to protect human rights is not absolute and must be combined with respect for the rights and guarantees granted to the foreign investor. ${ }^{111}$ The tribunal thus concluded that it needed to balance these two principles. ${ }^{112}$ Yet after its initial acknowledgement of the right to water, the tribunal failed to mention it in its subsequent analysis, and it is unclear where, if ever, the right to water informs the tribunal's thinking or where it balances the right to water against investor rights.

Conversely, in Urbaser $v$. Argentina, ${ }^{113}$ which once again involved a water concession contract in Argentina, the tribunal made a concerted effort, for the first time, to address Argentina's human rights obligations relating to the right to water. ${ }^{114}$ The tribunal determined that the investor's claim to fair and equitable treatment had to be assessed in light of the high "measure of deference that international law generally extends to the right of domestic authorities to regulate matters within their own borders." 115 It also found that an investor's legitimate expectations should be assessed within the context of the host state's economic and social environment and its "leeway" to issue public interest regulations. ${ }^{116}$

More importantly, the tribunal noted that Argentina had a responsibility "to ensure the population's health and access to water and to take all measures required to that effect." 117 It further stipulated how Argentina's human rights obligations interacted with its investment treaty obligations, noting that the state's measures to protect the right to water could not "hurt the fair and equitable treatment standard because their occurrence must have been deemed to be accepted by the investor when entering into the investment .... In short, they were expected to be part of the investment's legal framework." 118

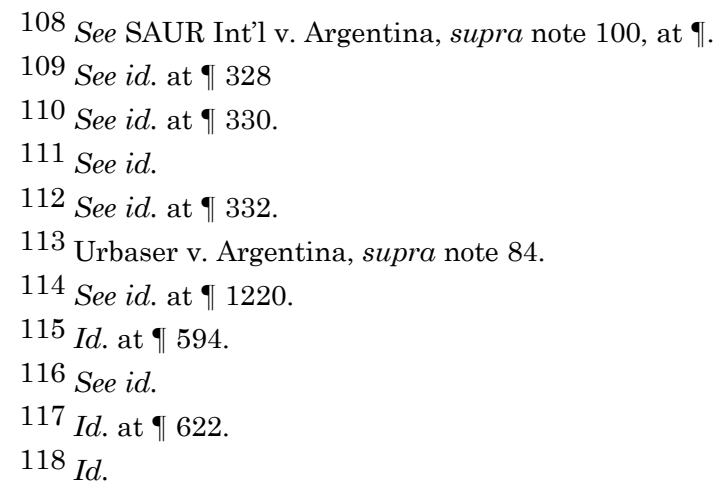


The tribunal's considerations of Argentina's human rights obligations, however, may have been prompted by the state's counterclaim in which it claimed that the investors had failed to meet their human rights obligations relating to water services. ${ }^{119}$ While the tribunal ultimately dismissed the counterclaim on the grounds that the investor was not obliged "to perform services complying with the residents' human right to access to water and sewage services," 120 it concluded that investors have obligations not to engage in activity aimed at destroying human rights. ${ }^{121}$

\section{The Right to Health}

As with the right to water, the idea that investment treaties may constrain a state's health obligations vis-à-vis its citizenry is well established. The UN Special Rapporteur on the Right to Health has observed that "[i]nternational investment agreements impose obligations on States vis-à-vis investors that may affect States' power to introduce health laws in the public interest. States may have to modify their laws to accommodate investors' rights, even though such modifications may increase the risk of violating individuals' right to health."122

An early example of the accommodations the Special Rapporteur is alluding to can be seen in Ethyl v. Canada. ${ }^{123}$ The dispute involved the investor challenging Canada's attempts to ban methylcyclopentadienyl manganese tricarbonyl (MMT), known to contain a neurotoxin. ${ }^{124}$ After losing its jurisdictional challenge, Canada settled with the investor, agreeing to reverse the ban and issue an official statement that it did not have any evidence that MMT caused harm. ${ }^{125}$ Notably, other countries, including the United States, the EU, and China, continue to prohibit or limit MMT for health reasons. ${ }^{126}$

However, in other investment arbitrations, tribunals have recognized the importance of a state's interest in protecting health issues, although such recognition has not always factored into the

\footnotetext{
119 See id. at 1156.

120 See id. at $\uparrow$ 1 1207-10.

121 See id. at 1199.

122 U.N. Secretary-General, Right of everyone to the enjoyment of the highest attainable standard of physical and mental health, ๆ 53, U.N. Doc. A/69/299 (Aug. 11, 2014).

123 See Ethyl Corp. v. Canada, UNCITRAL, Notice of Intent to Submit a Claim to Arbitration, ๆ ๆ 5-6 (Sept. 10, 1996).

124 JAMES P. WinTER, LIES THE MEDIA TELL Us 86 (2007).

125 See APPLETON \& Associates, Ethyl Corporation v. Canada, http://www.appletonlaw.com/files/cases_ethyl.pdf (last visited Oct. 25, 2019) [https://perma.cc/M243-ZCY7] (archived Oct. 25, 2019).

126 Ray Minjares, Update: MMT, INT'L COUNCIL ON CLEAN TRANSP. (Feb, 16, 2012), https://theicct.org/blog/staff/update-mmt [https://perma.cc/4439-DT25] (archived Oct. 25, 2019).
} 
tribunal's analysis. For instance, in S.D. Myers v. Canada, ${ }^{127}$ the state banned the transboundary export of $\mathrm{PCB}^{128}$ waste to prevent possible impairment to human life or health. ${ }^{129}$ Although the tribunal acknowledged the health risks associated with the transboundary movement of hazardous waste, it found that Canada should have used a less trade restrictive measure to fulfil its health objectives. ${ }^{130}$

Similarly, in Achmea B.V. v. Slovak Republic, ${ }^{131}$ where an investor sued the state after it changed the private health regulations in order to facilitate universal health coverage, ${ }^{132}$ the tribunal acknowledged the state's need to protect the right to health. As it observed, the investment treaty is not "hostile towards particular polices on the provision of health care facilities." 133 Nevertheless, the tribunal concluded that a state is obliged to compensate investors for efforts to increase health care protection. ${ }^{134}$

Conversely, in Methanex $v$. USA, ${ }^{135}$ the tribunal made great strides in establishing jurisprudence confirming the importance of a state's right to regulate health issues in the face of its investment obligations. The dispute involved the state banning the investor's investment for health reasons. However, the tribunal found that such a regulation enacted for a public purpose, which is nondiscriminatory and enacted with due process, can affect a foreign investment without constituting an expropriation or triggering compensation. ${ }^{136}$ While the tribunal did not refer to the right to health per se, it noted that the investor had entered a market in which comparable investments were commonly restricted for health reasons, and that the regulation in question, and the scientific studies confirming the health risks upon which it was based, were objectively confirmed. ${ }^{137}$

In Chemtura v. Canada, the tribunal echoed the reasoning in Methanex. ${ }^{138}$ The dispute involved a governmental regulatory

127 S.D. Myers, Inc. v. Canada, UNCITRAL, Partial Award (Nov. 13, 2000) [hereinafter SDMI v. Canada].

128 PCB refers to polychlorinated biphenyl (PCB) chemicals. See id. at 9 ๆ 90-100

129 See id. at 123.

130 See id. at 915.

131 Achmea B.V. v. Slovakia, PCA Case No. 2008-13 (Dec. 7, 2012).

132 See id. at 108.

133 Id. at $\uparrow 294$.

134 See id. (suggesting that the decision would have been if investors have been compensated for their efforts in increasing healthcare protection).

135 Methanex Corp. v. United States, UNCITRAL, Final Award (Aug. 3, 2005).

136 See id. at pt. 4, ch. D, 7 (explaining that as a matter of international law, a non-discriminatory regulation for a public purpose is expropriatary and compensable if specific commitments were given by the regulating government that it would not regulate).

137 Id. at pt. 4, ch. D, $₫$ ฯ 9, 14 .

138 Chemtura Corp. v. Canada, UNCITRAL, Award (Aug. 2, 2010). 
review and eventual phaseout of lindane, a pesticide, and the state specifically invoked its right to regulate to protect public health issues. ${ }^{139}$

The tribunal confirmed the reasoning in Methanex that public policy measures taken in a nondiscriminatory manner were not compensable, noting that Canada's acts in this dispute were "motivated by the increasing awareness of the dangers presented by lindane for human health." 140 The importance of protecting health also seemed to underlie the tribunal's analysis as it observed that its review of Canada's regulatory actions operated within the "broader factual context" 141 of the numerous countries that had banned or limited the use of lindane based on health concerns. ${ }^{142}$

In Eli Lilly $v$. Canada, the dispute involved pharmaceutical giant Eli Lilly challenging Canada's patent laws. ${ }^{143}$ As Canada argued, patent laws play a particularly relevant role in the pharmaceutical industry because they protect new and useful inventions and prevent major pharmaceutical corporations from using their deep pockets to patent "whole stables of chemical compounds" for unrealized purposes in hopes that one or more of those compounds will "serendipitously turn out to be useful." 144 This promotes innovation and ensures that patented products, including pharmaceuticals, actually deliver a particular level or type of utility. ${ }^{145}$

In dismissing all of the investor's claims, the tribunal found that Canada's patent laws had a legitimate public policy, in particular that the public received their end of the patent bargain, especially in connection with patents for the new use of a known compound. ${ }^{146}$ Moreover, it found that this legitimate public policy was rationally connected to Canada's patent laws. ${ }^{147}$ The tribunal therefore deferred to Canada's approach to regulating patents for pharmaceutical products, even while noting that Canada's approach may not have been the preferred one. ${ }^{148}$

\footnotetext{
${ }^{139}$ Id. at 183.

140 Id. at 9266.

141 See id.at 137 (noting that the factual context of lindane's danger was relevant in the tribunal's analysis).

142 Id. at 135 .

143 Eli Lilly \& Co. v. Canada, ICSID Case No. UNCT/14/2, Final Award (Mar. 16, 2017) [hereinafter Eli Lilly Award].

144 See Eli Lilly \& Co. v. Canada, ICSID Case No. UNCT/14/2, Canada's Statement of Defence, 19 (June 30, 2014) (explaining policy reasons for Canada's protection of its patent system).

145 See id. at 13, 21 (explaining that creation and protection of utility is the basis for Canada's patent system and, therefore, the benchmark against which inventions are judged).

146 Eli Lilly Award, supra note 144, at 423 (accepting respondent's claim that public receives its end of the bargain).

147 Id

148 Id. 428 (declining to decide whether Canada's approach is the preferred one, but concluding that the approach is not irrational).
} 
In another pharmaceutical-related dispute, Poland was held liable for failing to renew the marketing authorizations for two of the investor's pharmaceutical products. ${ }^{149}$ Poland argued that it had denied the marketing authorizations on the grounds of public health. ${ }^{150}$ The tribunal, while deferring to Poland's right to regulate in the public interest, 151 concluded that Poland's regulatory measures were discriminatory, disproportionate in nature, and not a matter of public necessity. ${ }^{152}$ As a result, it concluded that Poland was liable for expropriation. ${ }^{153}$ However, because the award's reasoning on public health is heavily redacted, it is impossible to definitively conclude whether Poland's right to protect its nationals' right to health was adequately considered by the tribunal.

Perhaps the most well-known health related investment arbitrations are those relating to tobacco-control measures. Tobacco giant Philip Morris challenged state measures to regulate tobacco usage in investment arbitrations against both Australia and Uruguay. While the Australian case was dismissed on jurisdictional grounds, ${ }^{154}$ the Uruguay case proceeded to a decision on its merits. ${ }^{155}$ In Philip Morris v. Uruguay, the investor challenged Uruguay's tobacco-control measures, including the single presentation requirement, which prevented tobacco companies from marketing more than one type of cigarette per brand family, ${ }^{156}$ and the 80/80 Regulation, which increased the size of prescribed health warnings on cigarette packages leaving less room for trademarks, logos, and other information. ${ }^{157}$

In dismissing all of the investor's claims, the tribunal made some important inroads in enlarging the right to health in the context of investment disputes. The tribunal noted that the expropriation provisions of an IIA must be interpreted in light of any relevant rules of international law, including customary international law, and that the protection of public health is well recognized as an essential manifestation of state police powers. ${ }^{158}$ It further found that Uruguay's measures were "adopted in fulfilment of [its] national and international legal obligations for

149 Les Laboratoires Servier, S.A.A. v. Poland, UNCITRAL, Award, ๆ 570 (Feb. 14, 2012).

150 See id. at 283 (claimant asserts that Poland denied marketing authorization on public health grounds).

151 Id. ๆ 569.

152 Id. ๑ 575.

153 See id. at 574 (finding divestment).

154 Philip Morris Asia, Ltd. v. Australia, UNCITRAL, PCA Case No. 2012-12, Award on Jurisdiction and Admissibility (Dec. 17, 2015).

155 Philip Morris v. Uruguay, supra note 84.

156 Id. at 10.

157 Id. at 11.

${ }^{158}$ Id. at ๆ 290-91. 
the protection of public health," 159 as the measures were proportionate to the objective they meant to achieve and were a "potentially effective means to protecting public health." 160 Moreover, since the measures were adopted in good faith and were nondiscriminatory, the tribunal concluded that these measures were a valid exercise of Uruguay's police powers and therefore could not constitute an expropriation. ${ }^{161}$

Similarly, in analysing the investor's claim for fair and equitable treatment, the tribunal infused its analysis with references to public health. For instance, it found that the measures were not arbitrary because they were a useful means to protect public health and there was ample evidence of health risks of cigarettes. ${ }^{162}$ The tribunal also held that the concept of the margin of appreciation should be applicable to claims arising under investment treaties, specifically noting " $[\mathrm{t}]$ he responsibility for public health measures rests with the government and investment tribunals should pay great deference to governmental judgments of national needs in matters such as the protection of public health."163

The tribunal went on to note that states should be given deference in exercising the discretionary exercise of their sovereign power so long as the power was not being exercised irrationally or in bad faith. ${ }^{164}$ Indeed, the sole inquiry for the tribunal should be limited to whether there was a manifest lack of reasons for the legislation. ${ }^{165}$ Moreover, they found that "substantial deference" should be given to a state's "decisions as to the measures which should be taken to address an acknowledged and major public health problem," while the reasonableness of a particular measure should be "assessed based on the situation prevailing at the time it was adopted."166

The tribunal further found that an investor's legitimate expectations could not be violated by a state's exercise of its normal regulatory power in the pursuance of a public interest unless specific undertakings were given. ${ }^{167}$ This would hold even if the regulation "breaks new ground," provided it has a rational basis and is nondiscriminatory. ${ }^{168}$ As the tribunal observed, Uruguay enjoys "unquestionable and inalienable rights to protect the health

159 Id. at 9302.

${ }^{160} I d$. at $\uparrow 306$.

161 Id. at $₫ 306-07$.

162 See id. at 9 391-92 (recognizing that Uruguayan measures are an effective means of protecting public health, and noting the existence of evidence indicating health risks).

163 Id. at 399.

${ }^{164} I d$.

$165 I d$.

166 Id. at $417-18$.

167 Id. at $9422-23$.

168 Id. at 430 ("Article 3.2 of the BIT does not preclude governments from enacting novel rules, even if these are in advance of international practice, provided these have some rational basis and are not discriminatory."). 
of its citizens," and it is within this framework to protect public health that Uruguay has the authority to act to enact tobaccocontrol measures. ${ }^{169}$

\section{Environmental Issues}

A third area in which investment law has impinged on noneconomic rights concerns the environment. Indeed, there are numerous links between human rights and the environment. Protection of the environment can have knock-on effects on related human rights, such as the right to health, the right to water, the right to an adequate standard of living, as well as other rights.

As with the early investment arbitrations relating to health, tribunals have been reluctant to accept the environmental dimensions of investment arbitrations. In Santa Elena v. Costa Rica, for instance, the state expropriated the investor's land by expanding the boundaries of a national park. ${ }^{170}$ The reason for the park's expansion was to "maintain stable populations of large feline species such as pumas and jaguars" and to preserve "flora and fauna of great scientific, recreational, educational, and tourism value, as well as beaches that are especially important as spawning grounds for sea turtles." ${ }^{171}$ In determining the amount of compensation owed to the investor for the taking, the tribunal held that the environmental purpose for the taking of the property did not "alter the legal character of the taking for which adequate compensation must be paid." ${ }^{172}$ It continued:

\footnotetext{
Expropriatory environmental measures-no matter how laudable and beneficial to society as a whole-are, in this respect, similar to any other expropriatory measures that a state may take in order to implement its policies: where property is expropriated, even for environmental purposes, whether domestic or international, the state's obligation to pay compensation remains. ${ }^{173}$
}

Marion Unglaube v. Costa Rica ${ }^{174}$ involved a very similar dispute to Santa Elena as it once again involved a situation in which Costa Rica expropriated the investor's land to create a national park, although this time it was for the purpose of protecting and nurturing the regeneration of the leatherback turtle. ${ }^{175}$ As with Santa Elena, the tribunal held that the

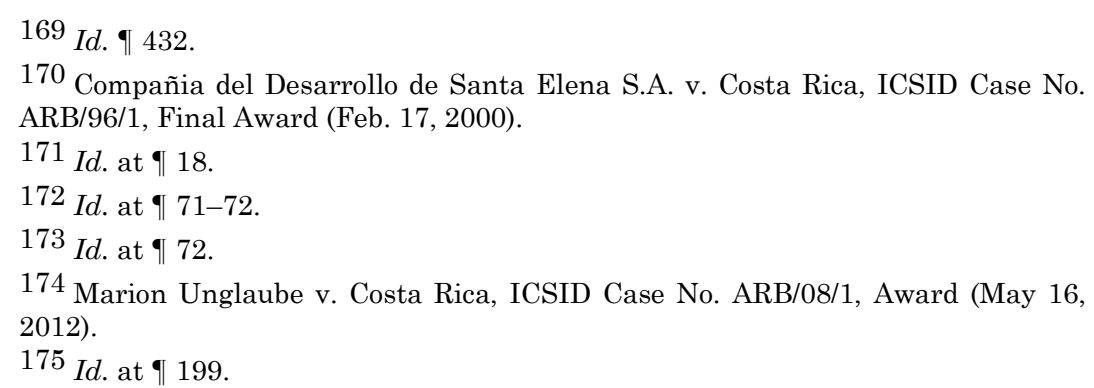


environmental purpose of the taking was not relevant to the dispute and concluded that although Costa Rica had the right to expropriate property for a bona fide public purpose, compensation was still due. ${ }^{176}$ However, in a muted sign of promise, the tribunal did note that Costa Rica should be given deference to regulate public policy issues ${ }^{177}$ and that the compensation owed to the investor should be calculated in light of environmental considerations. ${ }^{178}$

Tribunal recognition of environmental issues did not fare much better in Metalclad v. Mexico. ${ }^{179}$ In that case, Mexico prevented the investor from operating its hazardous waste landfill by denying it a permit to do so for, among other reasons, "ecological concerns regarding the environmental effect and impact" of the hazardous waste landfill site. ${ }^{180}$ The investor's ability to operate the hazardous waste landfill facility also became permanently precluded when the state issued an ecological decree protecting rare cacti around the land encompassing the landfill site. ${ }^{181}$

The tribunal concluded that Mexico had expropriated the investor's property by denying it the permit to operate the facility, despite its concern of the project's adverse environmental effects, as well as the enactment of the ecological decree preserving the cacti. ${ }^{182}$ In coming to this conclusion, the tribunal found that it was not required to decide or consider the motivation or intent behind the adoption of the ecological decree protecting the cactus, even though the passage of the decree, alone, constituted an expropriation. ${ }^{183}$

In S.D. Myers v. Canada, referred to above in the context of the right to health, the tribunal specifically referred to the environmental dimensions of the case. ${ }^{184}$ More specifically, the tribunal referenced both the environmental agreements signed by the parties as well as the NAFTA side agreement on the environment. ${ }^{185}$ However, the tribunal concluded that a state could only use a measure to protect the environment that is "most consistent with open trade." 186

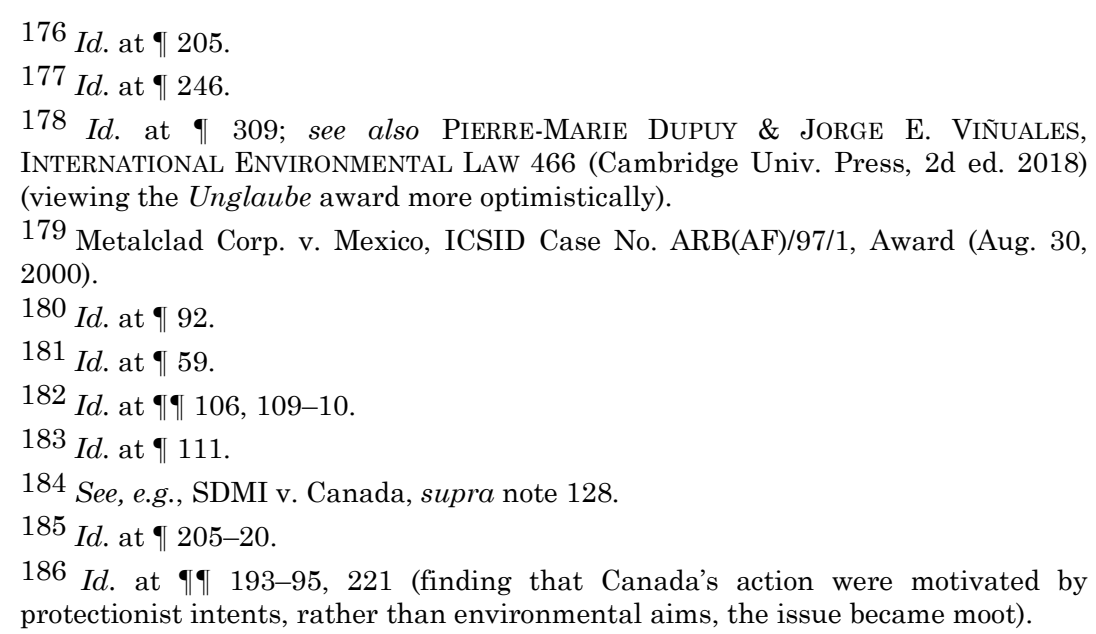


Environmental issues, alongside health issues, were also at issue in Tecmed $v$. Mexico. ${ }^{187}$ In the context of deciding whether the denial to grant the investor a permit to run a hazardous waste landfill constituted an expropriation, the tribunal observed that the "government's intention is less important than the effects of the measures on the owner of the assets." 188 Furthermore, it concluded that regulatory administrative actions, such as environmental protection measures, could be included within the scope of expropriatory acts even if they are beneficial to society as a whole. ${ }^{189}$

In Bilcon v. Canada, the majority of the tribunal similarly failed to accord much attention to environmental issues. ${ }^{190}$ Canada highlighted the environmental dimensions involved in the dispute from the outset, noting that the location of the investment was in an internationally recognized "extremely productive ecosystem with diverse plant and marine life," a breeding ground for five types of whales, a nationally recognized wildlife and migratory bird area, and a UNESCO designated biosphere reserve. ${ }^{191}$ It was thus, not surprising, that the project was subject to an environmental assessment, known as the Joint Review Panel (JRP). ${ }^{192}$ The scope of the JRP was not only to consider the environmental impacts of the project but also to consider the socioeconomic effects of the project, including whether the project went against community core values. ${ }^{193}$

In finding that Canada had violated its obligations of providing fair and equitable treatment and national treatment, the majority of the tribunal found that although the JRP had concluded that the project would lead to adverse environmental effects, ${ }^{194}$ it had not proposed any mitigation measures allowing the investor to address the environmental issues. In addition, the JRP had introduced the unsubstantiated concept of community core values into its analysis. ${ }^{195}$ However, the dissenting arbitrator emphasized that community core values were merely a proxy for "human

187 Técnicas Medioambientales Tecmed, S.A. v. Mexico, ICSID Case No. ARB(AF)/00/2, Award (May 29, 2003) [hereinafter Tecmed v. Mexico].

188 Id. at 116.

${ }^{189}$ Id. at 121.

190 Bilcon of Delaware, Inc. v. Canada, PCA Case No. 2009-04, Award on Jurisdiction and Liability (Mar. 17, 2015) [hereinafter Bilcon v. Canada].

191 Bilcon of Delaware, Inc. v. Canada, PCA Case No. 2009-04, Statement of Defence, I 8-10 (May 4, 2009) [hereinafter Canadian Statement of Defence]

192 See Bilcon v. Canada, supra note 191, at 215 (noting the Joint Review Panel was mandated to consider the socio-economic effects of a project, which can include an inquiry into whether the proposed project goes against the community's core values).

193 Id.

${ }^{194} I d$. at 188.

195 Id. at 9 505-06. 
environment effects," an element with which the investor had not engaged. ${ }^{196}$

The dissenting arbitrator further noted that the majority's decision fundamentally changed the manner of environmental reviews in Canada by introducing a new control over such reviews. ${ }^{197}$ As a result, a foreign investor who is unhappy with the decision of a Canadian environmental review panel will now be able to seek a remedy under the NAFTA, and if successful, be awarded damages for such a decision, despite the fact that there is no comparable damage award under Canadian law. ${ }^{198} \mathrm{He}$ thus prophesied that such a practice would "create a chill on the operation of environmental review panels." ${ }^{199}$ Moreover, because the award discounted the human environment effects of the project, he argued that this would cause future environmental review panels in Canada to subjugate such concerns to the scientific and technical feasibility of a project. ${ }^{200}$ This would change the manner of environmental review in Canada and result in "a remarkable step backwards in environmental protection."201

The notion of human environment effects closely links human rights to the environment, a right formally recognized as the right to a safe, clean, healthy, and sustainable environment. This right ensures that states adopt and implement legal frameworks to protect against environmental harm that may infringe on the enjoyment of human rights and it was the subject of at least one known arbitration. ${ }^{202}$ In Pac Rim v. El Salvador, ${ }^{203}$ amici curiae argued that the actions taken by El Salvador were designed to protect the right to a healthy environment against the risks posed by the investor in connection with its extractive operations. ${ }^{204}$ Although the tribunal accepted amici curiae's submissions, it refrained from engaging with the issue. ${ }^{205}$ Its reasoning was based on the fact that the amici curiae were not "made privy to the mass of factual evidence" and on the grounds that the tribunal was not required to consider this issue. ${ }^{206}$ As a result, it concluded that it would be "inappropriate" to do so. ${ }^{207}$ Since the tribunal dismissed

196 Bilcon of Delaware, Inc. v. Canada, PCA Case No. 2009-04, Dissenting Opinion of Professor Donald McRae, I 29 (Mar. 10, 2015) (who dissents from the Tribunal's finding with respect to Canada's breach of Article 1105).

197 Id. at 9 व $2,35$.

198 Id. at 48.

199 Id.

$200 I d$. at 949.

$201 \mathrm{Id}$. at 51.

202 John H. Knox, Mapping Report, ๆ 72, U.N. Doc. A/HRC/25/53 (30 Dec. 2013) (Independent Expert on the issue of human rights obligations relating to the enjoyment of safe, clean, healthy and sustainable environment).

203 Pac Rim Cayman LLC v. El Salvador, ICSID Case No. ARB/09/12, Award (Oct. 14, 2016).

204 Id. at 3.29 .

205 Id. at 3.30

206 Id.

207 Id. 
all of the investor's claims against El Salvador, it is unclear as to whether the tribunal was practicing judicial economy in refraining from engaging with the right to a healthy environment or whether it considered the issue unimportant.

In several instances, tribunals have recognized the importance of environmental issues but have held the state to a high standard for doing so. Indeed, where a state cannot justify its environmental policies or implements or enforces them unjustly, tribunals have been quick to hold the state liable. ${ }^{208}$ For instance, in Gold Reserve $v$. Venezuela, ${ }^{209}$ the tribunal acknowledged the state's responsibility to preserve the environment and protect the population living in the area surrounding the investor's mining activities. ${ }^{210}$ However, it went on to note, "this responsibility does not exempt a State from complying with its commitments to international investors by searching ways and means to satisfy in a balanced way both conditions." ${ }^{211}$ As a result, it held the state liable for failing to give the investor an opportunity to be heard before it revoked its permit on environmental grounds. ${ }^{212}$

Similarly, in Crystallex v. Venezuela ${ }^{213}$ the tribunal held that an investor did not have a "right" to a permit. ${ }^{214}$ Rather, a state has a sovereign prerogative to deny a permit, but, in doing so, it must provide the investor with "a precise and reasoned denial" that would enable the investor "a true opportunity to challenge that denial ... or to remedy the deficiencies of the project." 215 In finding the state liable, the tribunal noted that Venezuela had raised environmental concerns only in vague terms, without any supporting authorities, and that it had raised concerns about global warming without having ever previously communicated such concerns to the investor. ${ }^{216}$

\footnotetext{
208 See Saar Papier Vertriebs GMBH v. Poland, Final Award, ๆ 93(c) (Oct. 16, 1995) (observing that because the state could not justify its ban on an environmental policy ground, it should be held liable); see also Abengoa v. Mexico, ICSID Case No. ARB(AF)/09/2, Award, ๆ 619 (Apr. 18, 2013); MTD Equity Sdn. Bhd. v. Chile, ICSID Case No. ARB/01/7, Award, I 163 (May 25, 2004) (noting that presence of minister in investment approval process would not have made a difference because of inconsistent government action); Paushok v. Mongolia, UNCITRAL, Award on Jurisdiction and Liability, \ 696 (Apr. 28, 2011); Quiborax v. Bolivia, supra note 68, at 9 व 219-220.

209 Gold Reserve Inc. v. Venezuela, ICSID Case No. ARB(AF)/09/1, Award (Sept. $22,2014)$

210 Id. at 595.

211 Id.

212 Id. at 600.

213 Crystallex Int'l Corp. v. Venezuela, ICSID Case No. ARB(AF)/11/2, Award, (Apr. 4, 2016).

214 Id. at 951.

215 Id. at 993 .

216 See id. at I 592-96 (explaining that the supporting evidence offered is questionable and insufficient).
} 
In Copper Mesa v. Ecuador, the tribunal echoed the sentiment of the Crystallex tribunal that the investor should be given the opportunity to challenge the state's resolutions terminating its mining concessions. ${ }^{217}$ Ecuador argued that its measures were adopted to protect public health and the environment and requiring the investor to complete an environmental impact survey was needed to protect the local community and to reduce the environmental impacts of mining activities. ${ }^{218}$ While the tribunal found that the state should be able to self-define its national interests and public purposes, it found the state's conduct to be lacking because it had not given the investor the due process to challenge the state's resolutions. ${ }^{219}$ It also concluded that the state should have assisted the investor in completing its environmental assessment, despite the vocal protests over the environmental effects of the mine by protesters. ${ }^{220}$

A similar practice can be observed in Windstream Energy $v$. Canada. ${ }^{221}$ In Windstream, Canada argued that its decision to defer offshore wind projects-the subject of the investor's complaint-was grounded in the precautionary principle, which involved "waiting until sufficient research had been conducted, so that an adequately informed policy framework could be developed." 222 The tribunal accepted this argument noting that Canada's actions were driven "by a genuine policy concern that there was not sufficient scientific support for establishing an appropriate setback, or exclusion zone, for offshore wind projects." 223 However, the tribunal concluded that Canada did not do enough to address the scientific uncertainty surrounding the project, ${ }^{224}$ either by completing the required scientific research and allowing the project to proceed or by excluding offshore wind projects altogether and terminating the investor's contract. ${ }^{225}$

Despite the practice of many tribunals discounting environmental issues, more recent cases suggest that there may be a growing trend towards tribunals engaging with environmental issues. For instance, in Al Tamimi v. Oman, the tribunal interpreted the minimum standard of treatment standard in light of the importance of environmental protection. ${ }^{226}$ In doing so, the tribunal drew from the separate chapter on the environment in the treaty as well as a provision in the investment chapter enabling the

217 Copper Mesa Mining Corp. v. Ecuador, PCA No. 2012-2, Award (Mar. 15, 2016).

218 Id. at 6.16

219 See id. at $96.64,6.79,6.83$ (explaining that the state did not assist claimant in completing its duties after its resolution rendered completion impossible).

220 Id. at ๆ $6.83-6.84$.

221 Windstream Energy LLC v. Canada, PCA Case No. 2013-22, Award (Sept. 27, 2016) [hereinafter Windstream v. Canada].

222 Id. at 207.

223 Id. at 376 .

224 Id. at 378.

225 Id. at 979.

$226 \mathrm{Al}$ Tamimi v. Oman, supra note 84. 
state to ensure that investment was undertaken in a manner sensitive to environmental concerns. ${ }^{227}$ As the tribunal noted, in determining a breach of the minimum standard of treatment, it must be "guided by the forceful defence of environmental regulation and protection" language in the treaty. ${ }^{228}$

Similarly, in Bogdanov v. Moldova, the tribunal observed that the state's aim of protecting the environment is legitimate and that therefore the imposition of environmental charges cannot, in and of itself, violate the fair and equitable standard. ${ }^{229}$ Likewise in Plama v. Bulgaria, the tribunal noted that an investment treaty does not protect investors against changes to the host country's laws. ${ }^{230}$ Thus, Bulgaria could change its environmental laws, without liability, unless it had made specific promises or representations to the investor. ${ }^{231}$

The recent award in Aven v. Costa Rica ${ }^{232}$ suggests that some tribunals may even be inclined to prioritize environmental issues over investment issues. The case involved a tourism project in Costa Rica, which was later prohibited by the government after it was revealed that it impacted on wetlands and forests. ${ }^{233}$ The investors alleged breaches of FET and indirect expropriation, while the state counterclaimed that the works undertaken by the investor "caused considerable environmental damage" which they should repair and restore. ${ }^{234}$

The tribunal found that the treaty contained a provision that enabled a state to enact a measure, otherwise consistent with the investment chapter of the treaty, to attend to environmental concerns. ${ }^{235}$ This provision, the tribunal found, subordinated the rights of investors to the state's right to ensure the investment attended to environmental concerns, so long as the state's actions were fair and nondiscriminatory in nature. ${ }^{236}$ Having found that wetlands and the forest were impacted by the investor's project, the tribunal concluded that Costa Rica's actions in halting the project were justified and dismissed all of the investor's claims. ${ }^{237}$

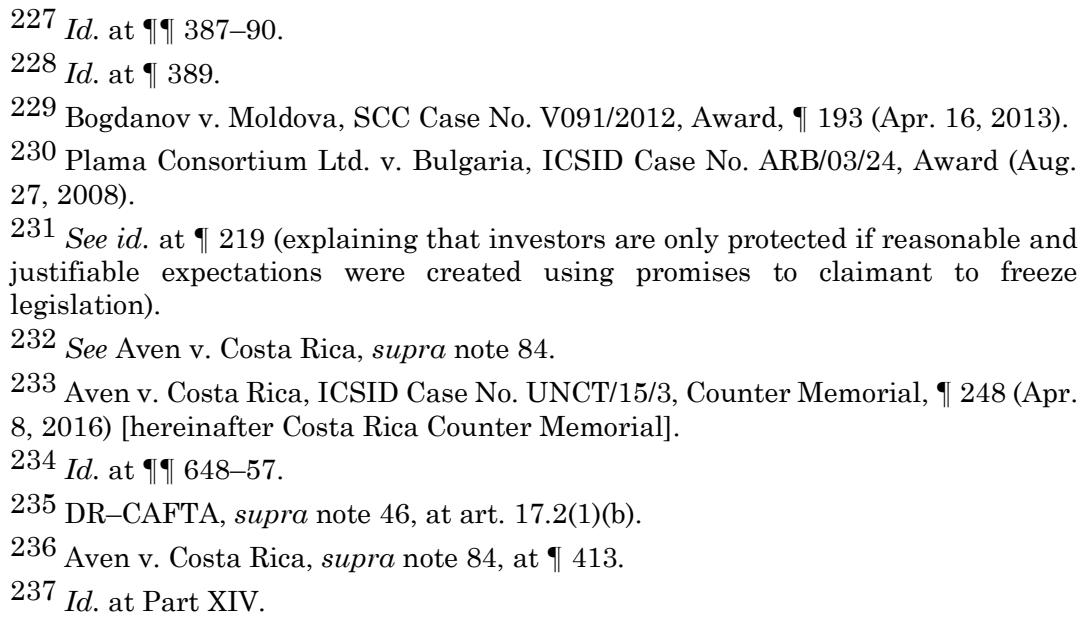


In considering the counterclaim, the tribunal concluded that foreign investors could be subject to international law obligations relating to the environment. ${ }^{238}$ However, such obligations would not be affirmative in nature. ${ }^{239}$ Moreover, an investor's breach of a state's environmental regulation would not arise to a breach of the treaty. ${ }^{240}$

Perhaps tribunal recognition of the environmental issues in Aven is a reflection of the state's environmental-related counterclaim. At least two other awards have involved states using counterclaims to highlight environmental issues in investment disputes that have been well received by arbitral tribunals. ${ }^{241} \mathrm{In}$ Perenco v. Ecuador, Ecuador counterclaimed against the investor alleging that it had caused an "environmental catastrophe" by operating oil blocks in the Amazon rainforest. ${ }^{242}$ The tribunal found the investor's conduct troubling and one that did not "paint a picture of a responsible environmental steward." 243 After consulting with an independent expert, the tribunal awarded damages to Ecuador in the amount of USD \$54 million. ${ }^{244}$

In a related arbitration, Burlington Resources Inc. $v$. Ecuador, ${ }^{245}$ Ecuador counterclaimed against Perenco's partner alleging breaches of Ecuadorian environmental law and contractual obligations and seeking compensation of approximately $\$ 2.8$ billion. The tribunal defined environmental harm as significant loss or impairment to the pre-existing conditions in the environment or one of its components, subject to applicable limits. ${ }^{246}$ The tribunal engaged in a thorough review of the investor's oilfields, classified each site, and ruled on any contamination claimed at each site. ${ }^{247}$ However, where it was difficult to determine appropriate classifications for the sites, the tribunal applied "the principles of precaution" in Ecuador's favour, ultimately awarding the state USD $\$ 41.7$ million in damages. ${ }^{248}$

In addition to counterclaims, states may be highlighting environmental issues as a jurisdictional issue. ${ }^{249}$ In Cortec $v$.

\footnotetext{
238 See Aven v. Costa Rica, supra note 84, at 9 ๆ 737-38 (concluding that investors operating internationally are immune from international law). 
Kenya, ${ }^{250}$ the tribunal recently accepted such a claim, wherein it declined the investor's claim at the jurisdiction stage on the grounds that it had not obtained an environmental impact assessment licence. As the tribunal observed: "The text and purpose of the BIT and the ICSID Convention are not consistent with holding host governments financially responsible for investments created in defiance of their laws fundamental [sic] protecting public interests such as the environment."251

Finding that the investor's failure to comply with Kenya's environmental regulations was of "fundamental importance" 252 and which showed "serious disrespect" 253 for the state's environmental policies, the tribunal held that the proportionate response was to deny the investor protection under the treaty. ${ }^{254}$

\section{The TREATMENT OF NONECONOMIC Rights At ODDS WiTH DEVELOPMENT IN INVESTMENT ARBITRATIONS}

The review of human rights and environment-related investment arbitrations confirms that investment arbitrations have compromised development goals in several instances. This has occurred by tribunals failing to engage with these issues in the course of arbitrations or in negating them altogether. These compromises remain problematic despite high profile cases such as Philip Morris or Urbaser ultimately being decided in favour of the state. ${ }^{255}$ IIA advocates have cited such cases as proof that problems of states not being able to regulate human rights or environmental issues are overblown. ${ }^{256}$ Yet, as the review of cases has shown, such cases are the exception not the norm. Indeed, for every Philip Morris, Methanex, or Urbaser decision affirming a state's public interest regulatory powers, there are cases such as Bilcon, Azurix,

\footnotetext{
250 See, e.g., Cortec v. Kenya, supra note 84.

251 Id. at 333 .

252 Id. at 946

253 Id. at 949

254 Id. at 9365 .

255 See Philip Morris v. Uruguay, supra note 84; Urbaser v. Argentina, supra note 84.

256 See, e.g., Symposium, Indirect Expropriation: Is the right to regulate at risk?, 2 OECD (Dec. 12, 2005) (noting "the Methanex award alone goes a long way toward justifying the conclusion that investment arbitrations are not putting at risk the right to regulate."); Nikos Lavranos, After Philip Morris II: The "regulatory chill" argument failed-yet again, KLUWER ARBITRATION BLOG (Aug. 18, 2016), http://arbitrationblog.kluwerarbitration.com/2016/08/18/after-philipp-morris-ii-theregulatory-chill-argument-failed-yet-again/ [https://perma.cc/Q7EA-LELH]
} (archived Nov. 12, 2019). 
Copper Mesa, CMS Gas, and so on, countering any suggested progress. ${ }^{257}$

The compromises to development ideals also persist despite states statistically "winning" investment arbitrations more often than investors. ${ }^{258}$ While these wins could suggest that state regulatory powers are adequately protected by investment arbitration, these statistical wins are actually a misnomer. In actuality, states do not "win" investment arbitrations as they are only entitled to cost awards. Moreover, in some instances, cost awards do not fully cover the litigation and opportunity costs states have faced in defending investment arbitrations, particularly those that have challenged human rights or environmental-oriented regulations. For instance, in Chemtura v. Canada, Canada's litigation costs were approximately USD $\$ 9$ million although it was only awarded costs of USD $\$ 6$ million. ${ }^{259}$ Canadian taxpayers thus bore USD $\$ 3$ million in costs for the government to defend its efforts to protect public health.

In addition, statistical counting of state "wins" does not take into account the increasing number of settlements between the parties. While settlements have not been subject to robust studies, Rob Howse's recent study into this area reveals that settlements tend to involve either "significant monetary relief for the investor" or, more troubling, "significant adjustment of the regulatory framework to the benefit of the investor." ${ }^{260}$ An example of the latter consequence is seen in relation to the Vattenfall v. Germany dispute. ${ }^{261}$ In that dispute, the investor brought an investment arbitration against Germany for-in the investor's words-the "extremely severe" 262 restrictions imposed by the state on an operating permit. The restrictions were designed to protect the Elbe River upon which the investor's coal plant would operate as well as mitigate the climate change impacts of the plant. ${ }^{263}$

257 See, e.g., Azurix Corp. v. Argentina, supra note 82; CMS v. Argentina, supra note 82; Bilcon v. Canada, supra note 191; Copper Mesa Mining Corp. v. Ecuador, supra note 218.

258 See Susan D. Franck \& Lindsey E. Wylie, Predicting Outcomes in Investment Treaty Arbitration, 65 Duke L.J. 459, 459 (2015); Matthew Hodgson \& Alistair Campbell, Damages and Costs In Investment Treaty Arbitration Revisited, 14 INT'L J. COM. TREATY ARBitration 4 (2017).

259 See Cris Best, Chemtura v. Canada: The Federal Government Successfully Defends NAFTA Claim Resulting from Pesticide Ban, TheCouRT.CA (Sept. 8, 2010), http://www.thecourt.ca/chemtura-v-canada-the-federal-government-successfullydefends-nafta-claim-resulting-from-pesticide-ban/ [https://perma.cc/3LMX-3Q73] (archived Oct. 19, 2018).

260 See Robert Howse, International Investment Law and Arbitration: A Conceptual Framework 65 (N.Y.U. Inst. for Int'l L. \& Just., Working Paper No. 17, 2017).

261 Vattenfall v. Germany, ICSID Case No. ARB/09/6, Award (Mar. 11, 2011) [hereinafter Vattenfall Award].

262 Vattenfall v. Germany, ICSID Case No. ARB/09/06, Request for Arbitration, ๆ 36 (Mar. 20, 2009) [hereinafter Vattenfall Request for Arbitration].

263 See, e.g., Sebastian Knauer, Vattenfall vs. Germany: Power Plant Battle Goes to International Arbitration, SPIEGEL ONLINE (July 15, 2009), http://www.spiegel.de/international/germany/vattenfall-vs-germany-power-plantbattle-goes-to-international-arbitration-a-636334.html [https://perma.cc/DU5Q- 
Germany settled the case with the investor and agreed, as part of the settlement, to drop the environmental-oriented restrictions that it had imposed as a condition of the investor's permit. ${ }^{264}$ It is not known whether the settlement also entailed Germany compensating the investor in any way. Interestingly, Vattenfall launched a second investment arbitration against Germany for its decision to phase out nuclear power, reportedly a decision made by Germany due to public opposition of nuclear power generation in the wake of a nuclear power disaster in Japan. ${ }^{265}$ The arbitration is currently pending and will surely pit health and environmental issues against investment ones once again. ${ }^{266}$

Finally, the number of state "wins" may be a misnomer for determining whether development ideals are being adequately addressed in investment arbitrations because it does not take into account the problem of regulatory chill. This is the idea that states may be unwilling to enact public interest regulations-for example to protect human rights or environmental issues-because they fear being the target of an investment arbitration if they choose to do so. ${ }^{267}$ As arbitrator Toby Landau has observed: "Without doubt, "regulatory chill" ... definitely exists, and there [is] palpable evidence of it." 268 Such evidence includes Indonesia having prevented its new environmental laws banning open pit mining from applying to foreign investors engaged in mining activities in the country when the investors threatened investment arbitration; ${ }^{269}$ New Zealand delaying the introduction of its tobacco plain packaging laws until Philip Morris' arbitration on the same issue with Australia was decided; ${ }^{270}$ and government officials in

C7ER] (archived Oct. 19, 2019) (explaining the background of Vattenfall vs. Germany).

264 Vattenfall Award, supra note 262, at art. 2.

265 See Vattenfall Request for Arbitration, supra 263.

266 Id.

267 See Kyla Tienhaara, Regulatory Chill and the Threat of Arbitration: A View from Political Science in Evolution In INVESTMENT TREATy LAW AND ARBitRation 606, 606 (Chester Brown \& Kate Miles eds., 2011) (describing the evidence and effects of regulatory chill).

268 ISDS: The devil in the trade deal, $\mathrm{ABC}$ (July 26, 2015), http://www.abc.net.au/radionational/programs/backgroundbriefing/isds-the-devilin-the-trade-deal/6634538 [https://perma.cc/X6DB-GKJN] (archived Oct. 22, 2019) [hereinafter Landau Comment].

269 Stuart G. Gross, Inordinate Chill: BITS, Non-NAFTA MITS, and Host-State Regulatory Freedom: An Indonesian Case Study, 24 MicH. J. INT'L. L. 893, 894 (2003); Kyla Tienhaara, What You Don't Know Can Hurt You: Investor-State Disputes and the Environment, 6 GLOBAL EnVTL. Pol. 73, 89 (2006).

270 See Eric Crosbie \& George Thomson, Why did it take 53 months for NZ to introduce plain cigarette packs?, NOTED (June 14, 2018,), https://www.noted.co.nz/health/health/plain-cigarette-packs-introduction-delayedin-nz/ [https://perma.cc/U2ST-VGHW] (archived Oct. 22, 2019) (detailing the process of introducing plain cigarette packs in New Zealand); Tariana Turia, Government moves forward with plain packaging of tobacco products, BEEHIVE (Feb. 20, 2013), https://www.beehive.govt.nz/release/government-moves-forward-plain- 
Ontario, Canada, now routinely vetting legislative proposals to ensure they do not trigger NAFTA Chapter 11 arbitrations. ${ }^{271}$ Landau further confirms that he is advising governments on the implications or consequences of a particular policy in terms of investment arbitrations and that governments are tending to move away from a particular policy if it risks triggering an investment arbitration. ${ }^{272}$

Moreover, some commentators have raised concerns that investors are using investment arbitrations as a strategy to delay or discourage regulation either in the defendant state or in a third state. ${ }^{273} \mathrm{~A}$ recent study has already found that investment arbitrations are prompting undisclosed settlements. ${ }^{274}$ OECD author Pohl thus theorizes that it is feasible that investment arbitrations may well be thwarting government regulatory efforts in secret as well. ${ }^{275}$ Given these concerns, it seems clear that IIAs continue to threaten development ideals, particularly those relating to human rights and the environment.

\section{The LEGAL RELATIONSHIP BETWEEN INVESTMENT TREATIES AND NONECONOMIC ISSUES}

Tribunal reluctance to include noneconomic issues within their analysis and interpretation of investment treaties is somewhat surprising given that international law espouses the concept of systemic integration. ${ }^{276}$ As the Vienna Convention on the Law of Treaties specifies, international treaties should be interpreted against the background of "relevant rules of international law applicable in the relations between the

packaging-tobacco-products [https://perma.cc/KH5B-QSY4] (archived Oct. 22, 2019) (describing the process leading to New Zealand adopting plain packing of tobacco products).

271 Gus van Harten \& Dayna N. Scott, Investment Treaties and the Internal Vetting of Regulatory Proposals: A Case Study from Canada, InV. TREATY News (Sept. 26, 2017), https://www.iisd.org/itn/2017/09/26/investment-treaties-internal-vettingregulatory-proposals-case-study-from-canada-gus-van-harten-dayna-nadine-scott/ [https://perma.cc/D8CN-ABZL] (archived Oct. 22, 2019).

272 Landau Comment, supra note 269.

273 See Krzysztof J. Pelc, What Explains the Low Success Rate of Investor-State Disputes?, 71 INT'L ORG. 559, 566 (2017) (explaining the increased rate of litigation is, in part, a result of higher perceived gains); Joachim Pohl, Societal Benefits and Costs of International Investment Agreements: A Critical Review Of Aspects and Available Empirical Evidence 65 (OECD Working Papers on Int'l Inv. 2018/01) (assessing the range of issues associated with the societal benefits and costs of International Investment Agreements).

274 See Emilie Hafner-Burton et al., Against International Settlement? The Social Cost of Secrecy in International Adjudication 46 (U.C. San Diego Sch. Glob. Policy \& Strategy, Working Paper No. 26, 2016) (providing statistics that provides evidence that cases hidden from public view are more likely to be kept secret through settlement).

275 Pohl, supra note 274, at 65.

276 See Int'l L. Comm'n, 58th Sess., Conclusions of the Work of the Sutdy Group on the Fragmentation of International Law: Difficulties arising from the Diversification and Expansion of International Law, U.N. Doc. A/61/10 ๆ 251 (2006). 
parties." ${ }^{277}$ Customary international law similarly confirms the concept of systemic integration. ${ }^{278}$ Moreover, the ICSID Convention, the NAFTA, and the Energy Charter Treaty specify that investment disputes shall be decided in accordance with the agreement or the law of the state in addition to the applicable rules of international law ${ }^{279}$ while several IIAs specify international law as the applicable law for the dispute. ${ }^{280}$ As the Phoenix tribunal confirmed, international investment law should be read and interpreted in accordance with public international law. ${ }^{281}$ Thus, to the extent noneconomic issues are found in relevant rules of international law, the interpretation of investment treaties must be done against the background of these rules.

Yet beyond integration, interpretation of investment treaties may further face instances where they must not only take into account noneconomic interests, but in some cases, yield to them. For instance, human rights issues that are embodied within jus cogens or peremptory norms of international law clearly trump any investment treaty obligation. ${ }^{282}$ Accordingly, a state would not be expected to meet its investment treaty obligations where the investor has engaged in torture, genocide, or slavery. ${ }^{283}$ Similarly, state obligations in the UN Charter should prevail over all other treaties, including investment treaties. ${ }^{284}$ In particular, the UN Charter specifically references development, compelling states to promote higher standards of living and conditions of social progress and development, in addition to promoting universal respect for human rights. ${ }^{285}$ Thus, the UN Charter arguably requires that investment treaties not be interpreted in a manner that denounces state efforts to promote higher standards of living and conditions of progress and development or detracts from efforts to promote human rights. ${ }^{286}$

277 Vienna Convention on the Law of Treaties, art. 31.3(c), May 23, 1969, 8 I.L.M. 679, 1155 U.N.T.S. 331 [hereinafter VCLT].

278 See LaGrand Judgment (Germany v. United States), 2001 I.C.J. 466, ๆ 99, (June 27) (applying the Vienna Convention as applicable law)

279 See ICSID Convention, supra note 29, at art. 42.1; NAFTA, supra note 45, at art. 1131; Energy Charter Treaty art. 26.6, Dec. 17, 1991, 2080 U.N.T.S. 100.

280 See Treaty Concerning the Reciprocal Encouragement and Protection of Investment, U.S.-Arg. art 2.2, Nov. 14, 1991, 31 I.L.M. 124 (requiring that investment be equitable under international law).

281 Phoenix Action Ltd. v. Czech Republic, ICSID Case No. ARB/06/5, Award, ๆ 78 (Apr. 15, 2009) [hereinafter Phoenix v. Czech Republic].

282 VCLT, supra note 278, art. 53; Prosecutor v. Furundžija, Case No. IT-95-17/1T, Judgment, ๆ 144,147 (Int'l Crim. Trib. for the Former Yugoslavia, Dec. 10, 1998).

283 Phoenix v. Czech Republic, supra note 282, at 98.

284 U.N. Charter, art. 103 [hereinafter U.N. Charter]; VCLT, supra note 278, at art. $30(1)$.

285 U.N. Charter, supra note 285 , arts. $55-56$.

286 See Legal Consequences for States of the Continued Presence of South Africa in Namibia Notwithstanding Security Council Resolution 276 (1970), Advisory 
Development ideals, including issues relating to human rights and the environment, may also be considered general principles of international law. They are therefore among the sources of international law 287 that tribunals are required to consider in interpreting investment treaties. ${ }^{288}$ Commentators have argued that such general principles of law may arise not only from international treaties and customary international law, but through "direct and spontaneous state consensus," UN General Assembly resolutions, multilateral treaty preambles, and national and/or international court judgments as well. ${ }^{289}$ Several human rights norms are well established through international treaties, such as the International Covenant on Economic, Social and Cultural Rights 290 and customary international law. ${ }^{291}$ Environmental norms, although less well established than human rights norms, can also be found in treaties and, to a lesser extent, in customary international law. ${ }^{292}$ Furthermore, the need to protect against challenges posed by environmental degradation was recently confirmed in a UN General Assembly resolution. ${ }^{293}$ Consequently, as sources of international law, tribunals have leeway to consider human rights and environmental norms as part of their broader approach of using international law to interpret investment treaties.

Still, incorporating human rights, environmental, or other development-related rules of international law as part of an effort of the systemic integration of international law or as a source of international law is unlikely to enable tribunals to resolve pronounced conflicts between investment treaty obligations and noneconomic issues in favor of the latter. As a result, the next Part

Opinion, 1971 I.C.J. 16, 131 (June 21) (interpreting the U.N. Charter to require non-discriminatory practices).

287 See U.N. Charter, Statute of the International Court of Justice, art. 38, ๆ 1 (specifying the sources of international law).

288 VCLT, supra note 278, at art. 31(3)(c).

289 See, e.g., GEBHARD BÜChELER, PROPORTIONALITY IN INVESTMENT ARBITRATION, 104-06 (2015); Philip Alston \& Bruno Simma, The Sources of Human Rights Law: Custom, Jus Cogens, and General Principles, 12 Australian Y.B. InT'L L. 82, 105 (1988); Stefan Kadelbach \& Thomas Kleinlein, International Law-A Constitution for Mankind? An Attempt at a Reappraisal with an Analysis of Constitutional Principles, 50 GERMAN Y.B. INT'L L. 303, 342 (2007).

290 See, e.g., G.A. Res. 2200A (XXI), International Covenant on Economic, Social and Cultural Rights (Dec. 16, 1966) (general assembly resolution based on U.N. Charter).

291 See, e.g., Brian D. LePard, Customary International LaW: A NeW Theory With PRACTICAL APPLICATIONS 3 (2010) ("The ICJ . . . has implied that the basic rights of the human person, including protection from slavery and racial discrimination have become part of the corpus of customary law."); THEODOR Meron, Human Rights AND Humanitarian Norms as Customary LaW 1 (1991) (noting human rights law norms bind states that are not parties to the instrument in which the norm is rested).

292 See generally DANIEL BODANSKY, ET AL., THE OXFord HANDBOOK OF INTERNATIONAL ENVIRONMENTAL LAW (2008) (providing a thorough overview of international environmental law).

293 See G.A. Res. 72/277, Towards a Global Pact for the Environment (May 14, 2018) (proposing the strengthening of environmental protections). 
turns to examine methods by which investment treaties can be reformed to better incorporate development ideals, thereby preventing (or limiting) such conflicts in the first place.

\section{REFORMING INVESTMENT TREATIES TO BETTER INCORPORATE DEVELOPMENT IDEALS}

If development is the ultimate aim of IIAs, states need to consider whether these treaties are the best vehicle for achieving this aim, even if such treaties are reconstituted to incorporate more elements consistent with development. As a commentator argues, investment treaties should not be humanized, but rather one should "envisage a world without an investment rules regime." 294 Not surprisingly, the World Bank takes a more pragmatic approach, noting that states withdrawing from the system must be mindful not only of the "costs of the policy reversal, but also the broader costs of reneging on an international commitment for which their partners will hold them accountable."295

UNCTAD's work on investor state dispute settlement (ISDS) reform, however, suggests that states are largely interested in reform rather than exit. ${ }^{296}$ Of course, not all states are interested in the same extent of reform. Some states champion only incremental changes while others prefer systemic or even paradigmatic changes. ${ }^{297}$ Nevertheless, the overriding trend seems to be continued state interest in investment treaties albeit with varying levels of reform. ${ }^{298}$

Because of the state interest in reform to investment treaties, this presents an opportune time to better incorporate development ideals into the treaties, both at the substantive and at the procedural level. While there is not always a clear division between substantive and procedural reforms - as they are often relatedthis Part first examines substantive reform ideas, focusing mainly on reworking substantive treaty standards and provisions, before turning to ideas to reform procedural issues.

294 David Schneiderman, Resisting Economic Globalization: Critical THEORY AND INTERNATIONAL INVESTMENT LAW 5 (2016).

295 World Bank, World Development Report 1997: The State In a Changing WORLD 101 (1997).

296 See Anthea Roberts, Incremental, Systemic, and Paradigmatic Reform of Investor-State Arbitration 113 AM. J. INT'L L. 410 (2018) (providing an overview of UNCTAD's recent reform effort on ISDS).

297 Id.

298 See id.; Sergio Puig \& Gregory Shaffer, Imperfect Alternatives: Institutional Choice And The Reform Of Investment Law, 112 AM. J. INT'L L. 361, 367 (2018) (discussing how states are proposing institutional reforms in UNCITRAL). 


\section{A. Substantive Reform}

As with other areas of international economic law, the idea of linkage - or establishing relationships between two areas of the law-is well established in international investment law. ${ }^{299}$ The natural solution for incorporating more development-related issues into an IIA would thus suggest that they be better linked to development goals, most notably by including greater references to human rights or environmental issues. However, in doing so, states must be mindful of how these issues are incorporated. In particular, framing the incorporation of development ideals through a human rights lens risks the possibility of investors seizing the reference to these rights for their own use. This is important because although tribunals have been reluctant to consider how investment issues affect citizens' human rights, they have been more willing to take into account how investors' human rights issues have been affected. ${ }^{300}$ Moreover, as the experience in US courts has shown, when corporations co-opt human rights issues for their own purposes, the end result can be very different from that imagined by human rights advocates. ${ }^{301}$ Conversely, incorporating human rights or environmental issues through references to sustainable development is less likely to increase the investor's arsenal of rights.

For many, reform to substantive treaty provisions should also aim to strike the right balance between investor protection and sovereign state regulatory rights. ${ }^{302}$ The concern is that without

299 See, e.g., VAlENTINA S. VADI, CUltural HERITAGe IN INTERNATIONAL INVESTMENT LAW AND ARBITRATION 48 (2014) (discussing the "linkage paradigm" between international cultural law and other branches of international law); CHRISTIAN J. TAMS ET AL., International Investment Law and the Global Financial Architecture: Identifying Linkages, Mapping Interactions, in INTERNATIONAL InVESTMENT LAW AND THE GLOBAL FinANCiAL ARChiteCtuRE 3-4 (2017) (“[P]arts of the international legal infrastructure governing the global market economy, international investment law and the global financial architecture have never been sealed off from one another."); Valentina S. Vadi, Reconciling Public Health and Investor Rights: The Case of Tobacco, in HUMAN RIGHTS IN INTERNATIONAL InVESTMENT LAW AND ARBITRATION 452 (Pierre Marie Dupuy et al. eds., 2009) (discussing linkage in the context of tobacco); Vid Prislan \& Ruben Zandvliet, Labor Provisions in International Investment Agreements: Prospects for Sustainable Development, Y.B. INT'L INV. L. \& POL'Y 3, 8 (2012-2013) (examining three factors that contribute to the main rationale for investment-labor linkage).

300 See Vivian Kube \& E.U. Petersmann, Human Rights Law In International Investment Arbitration, 11 ASIAN J. WTO \& INT'L HEALTH L. \& POL'Y 65, 73 (2016) (discussing that if applicable law clauses are sufficiently broad enough to include human rights violations, then adjudicating a human rights claim can be possible).

301 See Jose E. Alvarez, Are Corporations "Subjects" of International Law?, 9 SANTA ClARA J. INT'L. L. 1, 17-21 (2011) (raising concerns in connection with the Citizens United case in which the corporation argued that one of its "human" rights was being infringed).

302 See, e.g., U.N. CONF. ON TRAdE \& DEV., Investment Policy Framework for Sustainable Development, U.N. Doc. UNCTAD/DIAE/PCB/2015/5, 6 (2015); Congyan Cai, Balanced Investment Treaties and the BRICS, 112 AM. J. INT'L L. 191, 217 (2018) (discussing how treaty policies of BRICS countries vary in their approaches to reforming investor-state disputes); Prabhash Ranjan et al., India's Model Bilateral Investment Treaty: Is India Too Risk Averse?, BRookInGS INDIA 
achieving this balance, investors will be dissuaded from investing in foreign countries, as their foreign investments will not be safeguarded by the investment treaty provisions. ${ }^{303}$ As authors of a report critiquing India's new Model BIT observe, the BIT regime plays a role in attracting foreign investment, strengthens the rule of law, and improves the perception of foreign investors that it is easier to do business within the country. ${ }^{304}$ While these arguments in support of investment treaties are open to debate, states acting as both investment importers and exporters are more likely to require balanced treaties to ensure that their investors, when acting abroad, are adequately protected. ${ }^{305} \mathrm{~A}$ balanced treaty may also be integral to concluding IIAs with "key" states, such as the United States, the EU, and China. ${ }^{306}$

Thus, for some states, moving too far towards the protection of sovereign regulatory rights may be detrimental to the protection of their foreign investors or for concluding IIAs with certain states, making a balanced treaty imperative. Yet this argument is less true in other circumstances. For states acting primarily only as investment importers, not exporters, they do not necessarily need to be overly concerned with the protection of foreign investor rights, except when concluding treaties with states that demand such protections. In other words, apart from concluding IIAs with key states, there may be greater leeway for investment-importing states to include further protections for regulatory rights in IIAs. Moreover, investment importing states may be able to negotiate greater regulatory rights (i.e., less balanced) treaties with investment importing and exporting states who are cognizant of such issues. This could include states such as Canada, which is the developed country with the highest number of human rights and environmental-related investment arbitrations, or Norway, which has made efforts to conclude BITs with greater attention to regulatory concerns. ${ }^{307}$

As a result, there remains room for imbalance or greater protection of sovereign regulatory rights, if needed. This can be achieved by articulating the right to regulate, reforming the fair and equitable standard, including exception and other safeguard provisions, and creating investor obligation provisions.

IMPACT SERIES 5 (2018) (highlighting the problem in India that investors can bring legal claims against host states if the state's sovereign regulatory scheme is inconsistent with "bilateral investment treaties").

303 See Ranjan, supra note 303, at 38 (arguing that having a balanced investment treaty regime would help foreign investment in India).

304 Id.

305 See Cai, supra note 303, at 219 (emphasizing the need to balance state interests with those of overseas investors).

306 See id. at 219-20 (highlighting the need and effect of large western powers to adopt reform measures of balancing treaties).

307 See, e.g., Norway Model Bilateral Investment Treaty (2007); Norway Model Bilateral Investment Treaty (2015). 
1. The Right to Regulate

A simple mechanism for reinforcing a state's regulatory space for developmental goals is to formally articulate the state's right to regulate. For instance, the Morocco-Nigeria BIT specifies in its preamble "the right of the State Parties to regulate and to introduce new measures relating to investments in their territories in order to meet national policy objectives." ${ }^{08}$ The right to regulate may also appear as a separate provision of the treaty. The ArgentinaQatar BIT, for instance, specifies that nothing in the BIT shall affect the right of the state parties to regulate "through measures necessary to achieve legitimate policy objectives." 309

The effects of these types of provisions on state's regulatory space is typically muted since they neither create any legally enforceable rights or obligations nor create regulatory space. ${ }^{310}$ Rather, they perform "auxiliary functions" by denoting the weight to be accorded to specific public interests, offer a presumption that state regulatory interest will be taken into account, or confirm that investor protection obligations are not absolute. ${ }^{311}$ They may also help define the object and purpose of the BIT and its context, which in turn can be used in the interpretation of the treaty. ${ }^{312}$ Indeed, in Al Tamimi and Aven the tribunals drew on a treaty provision that enabled states to regulate investments to ensure they were undertaken in a manner sensitive to environmental concerns to interpret the fair and equitable treatment standard in light of environmental concerns. ${ }^{313}$

Thus, state declarations of the right to regulate may be helpful in a broader context of the overall interpretation of the BIT. However, on their own, they are unlikely to act as an adequate counter to investment protection provisions in BITs.

\section{Fair and Equitable Treatment}

\footnotetext{
308 Bilateral Investment Treaty, Nigeria-Morocco, pmbl., 2016. See also Bilateral Investment Treaty, Braz.-Malawi, pmbl., June 25, 2015 ("Desiring to encourage and strengthen contacts between private sector and the Governments of the two countries.") [hereinafter Brazil-Malawi BIT]; Bilateral Investment Treaty, Montenegro-U.A.E., pmbl., 2012 ("Desiring to create conditions for fostering greater investment by investors of one Party in the territory of the other Party."); Bilateral Investment Treaty, Indon.-Tunis., pmbl., 1992 ("Intending to create favourable conditions for investments by investors of one Party in the territory of the other Party on the basis of sovereign equality and mutual benefit.”).

309 Bilaterial Investment Treaty, Arg-Qatar, art. 10, 2016 [hereinafter ArgentinaQatar BIT].

310 AKATERINI TITI, The Right To REgULATE In International InVESTMENT LAW 104 (2014).

311 Vera Korzun, The Right To Regulate In Investor-State Arbitration: Slicing And Dicing Regulatory Carve-Outs, 50 VAND. J. TRANSNAT’L L. 355, 374 (2017); TITI, supra note 311 , at $104-05$.

312 VCLT, supra note 278, at art. 31(1).

313 See Al Tamimi v. Oman, supra note 84, at 9 387-390; Aven v. Costa Rica, supra note 84 , at 912 .
} 
Given that declaratory provisions do little to help establish state regulatory powers, particularly as they relate to development goals, reform must be directed at substantive provisions. As the review of human rights and environment-related investment arbitrations has shown, most claims in this area are centred around violations of expropriation and fair and equitable treatment. While the notion that state regulations should not be considered as expropriations was recognized as early as 1961 in the Harvard Draft Convention on the International Responsibility of States for Injuries to Aliens, ${ }^{314}$ investment treaties did not formally recognize this idea until around the early 2000s. ${ }^{315}$ However, by 2004, model BITs for Canada ${ }^{316}$ and the United States, ${ }^{317}$ among others, began to formally proclaim the disconnect between regulations and expropriations, stating, for instance, that: "Except in rare circumstances, non-discriminatory regulatory actions by a Party that are designed and applied to protect legitimate public welfare objectives, such as public health, safety, and the environment, do not constitute indirect expropriations." 318

One tribunal confirmed the difference between expropriations and regulations, noting that "[e]xpropriations tend to involve the deprivation of ownership rights; regulations a lesser interference." ${ }^{319}$ It is thus not surprising that, of the investment arbitrations surveyed, public policy regulations were less likely to constitute an indirect expropriation. ${ }^{320}$

However, while states have been careful to circumscribe the ambit of indirect expropriation provisions in IIAs and protecting regulatory powers in that context, they have not consistently made similar inroads into the area of fair and equitable treatment. FET claims have accordingly become the investor's preferred route to

314 Harvard Draft Convention on the International Responsibility of States for Injuries to Aliens Reprinted in Louis B. Sohn \& R. R. Baxter, Responsibility of States for Injuries to the Economic Interests of Aliens: II. Draft Convention on the International Responsibility of States for Injuries to Aliens, 55 AM. J. INT'L L. 548, art. 10(5) (1961).

315 See CAnada Model Foreign Investment and Promotion Act, Annex B.13(1)(c) (2004), https://www.italaw.com/documents/Canadian2004-FIPA-modelen.pdf [https://perma.cc/7SXG-BGFH] (archived Oct. 23, 2019) (mentioning the idea that state regulations should not be considered expropriations); U.S. Model Bilateral Investment Treaty, Annex B, art. 4(b), 2012, https://www.state.gov/documents /organization/117601.pdf [https://perma.cc/G82N-UJ5B] (archived Oct. 23, 2019) [hereinafter U.S. Model BIT] (mentioning the same idea as the model Canada Act). 316 CAnada Model Foreign Investment And Promotion ACt, supra note 317, at Annex B 13(1)(C).

317 U.S. Model BIT, supra note 316, at Annex B, art. 4(b)

318 Id.

319 SDMI v. Canada, supra note 128, at 282.

320 See id. (detailing that 16 out of 56 awards contained an (indirect) expropriation breach. Moreover, in many of those instances, the treaty in question was a pre-2004 treaty that did not contain the language excepting regulations from the ambit of indirect expropriation). 
investment arbitrations. ${ }^{321}$ As noted earlier, FET claims are particularly problematic in human rights and environment-related investment arbitrations since they constitute the bulk of successful investment arbitration claims in this area. ${ }^{322}$

Part of the problem with the FET standard is the vague and ambiguous terms it encompasses, which are undefined, and which are subject to open interpretation by tribunals. ${ }^{323}$ This has enabled the FET standard to take on a wide variety of meaning from due process to racial prejudice to transparency and beyond. ${ }^{324} \mathrm{In}$ particular, one especially problematic element tribunals have attributed to the FET standard is the concept of legitimate expectations. This is the idea that an investor has expectations of the host state, for instance, that the state will act free from ambiguity and transparently so that the investor may know beforehand all rules and regulations that will govern its investment. ${ }^{325}$ In the context of human rights-related and environment-related investment arbitrations, the concept of legitimate expectations has underpinned breaches of the FET standard in disputes such as Enron, ${ }^{326}$ Tecmed, ${ }^{327} \mathrm{CMS},{ }^{328}$ and Suez, ${ }^{329}$ among others. Tribunals have been especially critical of host states that have made regulatory changes that altered the legal framework of the investment. ${ }^{330}$ Under this view, the concept of legitimate expectations is treated as a type of stabilization clause wherein the host state's laws are expected to be frozen from the

321 See Muthucumaraswamy Sornarajah, RESistance AND CHANGE IN INTERNATIONAL INVESTMENT LAW, 247-48 (2013) (highlighting the problems in investment arbitration and current changes).

322 See SDMI v. Canada, supra note 128, at 9282 (just over half of the 56 awards surveyed contained a FET breach).

323 See Fair and Equitable Treatment, UNCTAD SERIES ON ISSUES IN INTERNATIONAL INVESTMENT AGREEMENTS II, 10-12, UNCT AD/DIAE/IA/2011/5 (2012) (mentioning the inconsistency in understanding the FET standard); FULVIO Maria Palombino, Fair and Equitable Treatment and the Fabric of General PRINCIPLES 20 (2018) (describing five different ways in which FET has been characterized); Güneş Ünüvar, The Vague Meaning of Fair and Equitable Treatment Principle in Investment Arbitration and New Generation Clarifications 6 (iCourts Working Paper Ser. No. 55, 2016) (arguing for the necessity of clarifications).

324 See Waste Mgmt. Inc. v. United States, 43 I.L.M. 967, ๆ 98 (2004) (racial prejudice); Martins Paparinskis, The International Minimum Standard AND FAIR AND EQUitable TREatMent 197, 228 (2013) (human right to fair trial and property); ROLAND KLÄGER, FAIR AND EQUiTABle TREATMENT IN INTERNATIONAL INVESTMENT LAW 213, 227 (2011) (fair procedure and transparency); Rudolf Dolzer, Fair and Equitable Treatment: Today 's Contours, 12 SANTA ClaRA J. INT'L L. 7, 29 (2014) (due process).

325 Tecmed v. Mexico, supra note 188, at 9154.

326 Enron Corp. v. Argentina, ICSID Case No. ARB01/3, Award, ๆ 262 (May 22, 2007).

327 Tecmed v. Mexico, supra note 188, at 9154.

328 See CMS v. Argentina, supra note 82.

329 See Suez v. Argentina, supra note 81

330 See, e.g., Enron v. Argentina, supra note 327, at 9 265 (ruling in favor of Enron's reasonable belief); Suez v. Argentina, supra note 81, 9 ๆ 226-31 (ruling against the changes made by the host state). 
time of the investment. ${ }^{331}$ Although there has been pushback from some tribunals on this interpretation of legitimate expectationsnotably, the Continental Casualty tribunal observed it would be "unconscionable for a country to promise not to change its legislation as time and needs change" 332 - the notion of legitimate expectations persists. This is despite the fact that neither treaty texts nor custom refer to legitimate expectations, and it is not a concept likely to have been contemplated by the parties to the treaties. ${ }^{333}$ It is thus purely an "arbitral innovation." 334

The ever-expanding FET standard, and particularly the concept of legitimate expectation, therefore, remains a moving target for states and a threat to state ability to regulate development-related issues. Accordingly, given the impact of FET claims to thwart human rights and environment-related issues, states should ensure the FET standard remains carefully circumscribed. One approach to doing so would be to remove the FET standard altogether. ${ }^{335}$ India has taken this approach in its newly revised model BIT, by replacing the FET standard with "treatment of investors." ${ }^{336}$ Such treatment prohibits measures "which constitute a violation of customary international law" and limits measures to denial of justice, breach of due process, targeted discrimination, or manifestly abusive treatment. ${ }^{337}$ By taking this approach, India has removed the ability of tribunals to develop content for the FET standard and has narrowed the grounds for state liability only to the enumerated grounds, notably excluding the concept of legitimate expectations and arbitrariness. This approach clearly foregoes the concept of balance for a decisive reorientation and strengthening of state sovereignty.

A second approach would be to retain the fair and equitable standard but continue to prescribe the grounds for breach of the standard. The Comprehensive and Progressive Agreement for Trans-Pacific Partnership has taken this approach, referring to the

331 Thomas W. Wälde \& George Ndi, Stabilizing International Investment Commitments: International Law versus Contract Interpretation, 31 TEX. INTL. L. J. 215, 220-24, 245 (1996).

332 Cont'l. Cas. v. Argentina, supra note 85, ๆ 258. See also Eiser Infrastructure Ltd. v. Spain, ICSID Case No. ARB/13/36, Final Award, ๆ. 362 (May 4, 2017) ("II]nvestment treaties do not eliminate States' right to modify their regulatory regimes to meet evolving circumstances and public needs."); EDF Services Ltd. v. Romania, ICSID Case No. ARB/05/13, Award, ๆ. 217-18 (Oct. 8, 2009) (quoting Parkerings v. Lithuania); Parkerings v. Lithuania, supra note 83, I 332 ("A state has the right to enact, modify or cancel a law at its own discretion. . . . any businessman or investor knows that laws will evolve over time.").

333 SORNARAJAH, supra note 322, at 256; PAPARINSKIS, supra note 325, at 253-56.

334 Dolzer, supra note 325 , at 9.

335 See generally Enrique Barrera, The Case for Removing the Fair and Equitable Treatment Standard from NAFTA (CIGI Papers No. 128, April 2017) (arguing for removing the standard entirely).

336 India Model BIT, supra note 55, at art. 3.1.

337 Id. 
FET standard in its investment chapter, but limiting its scope only to grounds of denial of justice in accordance with the principle of due process. ${ }^{338}$ It also goes on to note that the standard is the one prescribed by customary international law, that it cannot be triggered by breach of another provision of the agreement or a separate international agreement, and that an action by a state which is inconsistent with an investor's expectations does not constitute a breach of the standard. ${ }^{339}$ As with India's approach, this approach swings toward state sovereignty over balance.

For states searching for a more balanced approach, a third approach would be to delineate the grounds for the FET standard but to make provision for a review of the content of the standard if needed. The EU-Canada Comprehensive Economic and Trade Agreement adopts such an approach. It limits the FET standard to denial of justice, fundamental breach of due process, manifest arbitrariness, targeted discrimination, abusive treatment of investors, ${ }^{340}$ in addition to any treatment, as defined by the parties, developed subsequently to the signing of the agreement. ${ }^{341}$ The agreement also incorporates the concept of legitimate expectations, noting that in applying the FET obligation, a tribunal can consider whether a specific representation was made to an investor to induce an investment. ${ }^{342}$ It thus specifies legitimate expectations as a factor to be used to construct breaches of FET, not as an element of fair and equitable in and of itself.

A final approach, which swings in the direction of increased state sovereignty, would be to prescribe the elements of the FET standard, but to remove it from the scope of investor-state dispute resolution. As commentators have suggested, this would still require states to afford such treatment to investors, but disputes over treatment would be resolved through other means, such as through consultations or state-to-state dispute resolution. ${ }^{343}$

While states must decide for themselves whether they require a balanced or sovereigntist FET approach, from a developmental perspective, the most important reform to the FET standard would be to curtail arbitrator discretion to define its elements, for instance, by prescribing its elements. Yet even in prescribing FET's elements, states must ensure that the words used to define the FET elements are not, themselves, open to arbitral interpretation. For

\footnotetext{
338 CPTPP, supra note 45 , at art. 9.6.2(a).

339 Id. at art. 9.6.

340 Comprehensive Economic and Trade Agreement, Can.-E.U., art. 8.10(2), Oct. 30, 2016 [hereinafter CETA].

341 Id. at art. 8.10(3).

342 Id. at art. 8.10(4).

343 Mona Pinchis-Paulsen, A NAFTA Proposal: Fix the FET Investment Protection Commitment, INT'L ECON. L. \& POL'Y BLOG (Sept. 27, 2017), https://worldtradelaw.typepad.com/ielpblog/2017/09/a-nafta-proposal-fix-the-fetinvestment-protection-commitment-.html [https://perma.cc/VKW9-VKFV] (archived Oct. 22, 2019). See, e.g., Todd Tucker, Accountability in a Regime Complex: Charting Policy Reforms for Investor-State Dispute Settlement, PENAL ON JUDICIALIZATION INT'L REL. (2016).
} 
instance, in the EU-Canada CETA, manifest arbitrariness ${ }^{344}$ seems prone to being interpreted in a myriad of ways, leaving an opening for a judicially active arbitral tribunal. Similarly, given the expansive scope given by arbitral tribunals to the concept of legitimate expectations, a development perspective would suggest that this concept be left entirely out of the FET standard. To that end, the CFTPP adopts a prudent approach by specifically denouncing legitimate expectations, in and of itself, as an element of FET.

In addition, to further protect state ability to regulate for development goals, states should consider adding a section to the FET standard that further defines the standard, mimicking the wording found in indirect expropriation provisions. Thus, in the same way that indirect expropriation standards note that "nondiscriminatory regulatory actions that are designed and applied to protect legitimate public welfare objectives do not constitute indirect expropriations," FET standards should contain language that nondiscriminatory regulatory actions that are designed and applied to protect legitimate public welfare objectives do not constitute a breach of fair and equitable treatment. In doing so, state regulatory power becomes further insulated from the FET standard.

\section{Safeguard Provisions}

A third option for reform is to focus on provisions that safeguard the state ability to regulate. This includes exceptions provisions, provisions that exclude application of the treaty entirely, and reservations. For instance, in almost all of its post2012 treaties, Canada has borrowed some of the text of the general exceptions provisions found in the General Agreement on Tariffs and Trade (GATT). ${ }^{345}$ Canada denotes nonarbitrary measures that are necessary to protect human, animal, or plant life; or health; or that relate to the conservation of living or nonliving natural resources, among others, as exceptions to the IIA. ${ }^{346}$ Similarly, other states have specified measures that protect public morals, maintain public order, or measures that protect national treasures as general exceptions to their IIA obligations as well. ${ }^{347}$

\footnotetext{
344 CETA, supra note 342, at art. 8.10(2)(c).

345 Marrakesh Agreement Establishing the World Trade Organization, art. XX, Apr. 15, 1994, 1867 U.N.T.S. 154 [hereinafter Marrakesh Agreement]

346 See Bilateral Investment Treaty, Can.-China, art. 33, Sept. 8, 2012 (exceptions) [hereinafter Canada-China BIT].

347 See, e.g., ASEAN-India Investment Agreement art. 21, Nov. 12, 2014 (including public morals and animals); Agreement on Reciprocal Promotion and Protection of Investment, Iran-Japan, art. 13, Feb. 5, 2016 (including public morals); see also Economic Partnership Agreement, Japan-Mong., art. 1.10, Feb. 10, 2015 (incorporating GATT exceptions from 1994).
} 
This approach, however, raises two problems. First, it requires states to pass a "necessity" test to rely on the exception relating to human, animal, or plant life or health in addition to demonstrating that its measures are not arbitrary, discriminatory, or a disguised restriction on trade. ${ }^{348}$ The necessity test has proved particularly susceptible to tribunal interpretations, as the Argentinian financial crisis cases have demonstrated, suggesting that in many instances states will not be able to rely on such an exception. ${ }^{349}$ Some states have circumvented the necessity test problem by removing any reference to the word "necessary," enabling states to take measures simply "to fulfil" its obligations. ${ }^{350}$

A second problem with the use of GATT-style general exception provisions is that tribunals may treat the list of exceptions as exhaustive. In Bear Creek v. Peru, Peru attempted to argue that its actions were justified by the police powers exception. ${ }^{351}$ The investment treaty in question contained a general exceptions provision, but it did not make any specific reference to the police powers exception. ${ }^{352}$ The tribunal ruled that the general exceptions provision was exhaustive, thereby preventing Peru from relying on the police powers exception unless specifically provided for in the list of general exceptions. ${ }^{353}$ In other words, including a list of general exceptions curtailed the state's regulatory power to the enumerated grounds only rather than broadened them.

Rather than rely on some form of GATT-style language, some states have chosen to tie exceptions in their BITs to the specific regulatory power they wish to protect. For instance, BITs with Singapore ${ }^{354}$ or Mauritius ${ }^{355}$ contain an exception provision that provides the right of states to take any action directed to the protection of public health or protection of the environment. Similarly, in the Kenya-Korea BIT, the states commit to free

348 See Arthur Appleton, GATT Article XX's Chapeau: A Disguised 'Necessary' Test?, 6 REV. EuR., CoMP. \& INT'L ENVTL. L. 131, 136 (1997); Ming Du, The Necessity Test in World Trade Law: What Now?, ChINESE J. InT'L L. 817 (2016); Gisele Kapterian, A Critique of the WTO Jurisprudence on Necessary, 59 INT'L \& COMP. L.Q. 89, 90 (2010).

349 See Barnali Choudhury, Exception Provisions as a Gateway to Incorporating Human Rights Issues into International Investment Agreements, 49 ColuM. J. TRANSNAT'L L. 670, 697 (2011) (using the Argentinian cases to interpret the exception provisions).

350 See, e.g., Bilateral Investment Treaty, Egypt-Mauritius, art. 13, June 25, 2014 (using language "to fulfill") [hereinafter Egypt-Mauritius BIT]; Bilateral Investment Treaty, China-Sing., art. 11, Nov. 21, 1985 (using language "to apply") [hereinafter China-Singapore BIT].

351 Bear Creek Mining Corp. v. Peru, ICSID Case No. ARB/14/2, Award, ฯ 451-52 (Nov. 30, 2017) [hereinafter Bear Creek v. Peru].

352 Bilateral Investment Treaty, Peru-Can., art. 10, Nov. 14, 2006.

353 Bear Creek Mining Corp. v. Peru, supra note 353, at $973-74$.

354 See, e.g., Bilateral Investment Treaty art. 11, Viet.-Sing., Oct. 29, 1992; ChinaSingapore BIT, supra note 352 , at art. 11 .

355 See, e.g., Bilateral Investment Treaty, Mauritius-India, art. 11.3, Apr. 9, 1998 (public health exception); Egypt-Mauritius BIT, supra note 352, at art. 13 (public health exception). 
transfers of payments except in specified circumstances such as the threat of "external financial circumstances." 356 The United States, in its model BIT, specifies that the agreement will not impose obligations with respect to taxation measures unless otherwise provided. ${ }^{357}$ Several states also exempt state measures adopted for prudential reasons. ${ }^{358}$ Thus, the Iran-Slovakia BIT exempts state measures adopted to ensure the integrity and stability of the state's financial system from the scope of the BIT. ${ }^{359}$

Unlike using GATT-style language, tying exceptions to a specific regulatory aim ensures that the sovereign areas of control the state wishes to preserve are specifically targeted and protected. Nevertheless, it is unlikely that a state can ex ante predict all of the regulatory powers it wishes to protect. This suggests that such an approach is helpful but insufficient.

Accordingly, on the understanding that a state wishes to protect certain regulatory powers but cannot anticipate what all those powers might be, states have a number of options. First, if adopting GATT-style language, the state should specifically denote that the list of exceptions does not preclude the state's reliance on other exceptions or defences found in customary international law to prevent future Bear Creek problems. Alternatively, the state can codify the police powers exception either by adding it to its list of exceptions or by using it as a standalone provision. For example, following the holding in Methanex, states can include in the text of BITs the following wording: provided that it is not applied in an arbitrary or discriminatory manner and has been enacted with due process, a measure enacted for a public purpose which affects a foreign investment is not compensable.

Second, states can try to limit the interpretive discretion currently afforded to tribunals when interpreting safeguard provisions. This can be done by removing value-laden words such as "necessary" and replacing it with more factual based wording (such as "directed to"). Alternatively, it could involve including text denoting that a measure is self-judging. The China-Chile BIT, ${ }^{360}$ for instance, exempts measures that it considers necessary to protect its essential security interests, thereby preserving state control over deciding whether a measure is needed. ${ }^{361}$ Another approach is to give state parties sole authority to determine whether a state may rely on a particular safeguard provision. For

\footnotetext{
356 Bilateral Investment Treaty, Kenya-S. Kor., art. 6(3)-(4) Aug. 7, 2014.

357 U.S. Model BIT, supra note 316, at art. 21.

358 See, e.g., Bilateral Investment Treaty, Colom.-Turk., art. 2(4), July, 282014 (mentioning "prudential reasons" specifically); Canada-China BIT, supra note 348, at art. 33(3) (setting out specific "prudential reasons").

359 Slovakia-Iran BIT, supra note 50, at art. 11.2.

360 Bilateral Investment Treaty, H.K.-Chile, art. 6(b), Nov. 11, 2016 [hereinafter Hong Kong-Chile BIT].

361 SALACUSE, supra note 1 , at 381 .
} 
instance, the United States model BIT provides that the state parties must decide whether a taxation measure constitutes an expropriation before such a claim can be made in an investment arbitration. ${ }^{362}$ Similarly, the Australia-China FTA exempts measures for legitimate public welfare objectives from being subject to investment arbitration, but requires the state parties to provide a binding decision confirming whether the measure in question falls within the purview of this exception. ${ }^{363}$

Finally, states could subject disputes concerning regulatory measures aimed at protecting human rights and/or the environment to a different dispute resolution mechanism altogether. Such disputes could be regulated by state-to-state dispute resolution or by joint state party committees or ombudsmen as a means of limiting investor challenges to public policy regulations. More radically, states could exempt such regulatory measures from investment arbitration altogether. The CPTPP and some Singaporean BITs already employ such a practice with their tobacco carve-outs that enable state parties to deny investors the ability to bring an investment arbitration challenging a tobacco control measure. ${ }^{364}$ States could follow a similar practice for human rights/environmental protection-oriented measures and prohibit such measures from even being the subject of an ISDS claim.

\section{Investor Obligations}

A fourth option for reform is to create responsibilities for investors regarding state developmental goals. Today it is widely recognized that businesses have responsibilities not to harm people's human rights ${ }^{\mathbf{3 6 5}}$ or the environment, although IIAs do not reflect such responsibilities. Moreover, as the Urbaser tribunal has observed, an investor would only be required to bear a human right obligation if dictated by a contract or other legal relationship. ${ }^{366}$ Thus by creating such legal responsibilities for investors within IIAs, investors will be more likely to be prompted to assist states in achieving their development goals.

\footnotetext{
362 U.S. Model BIT, supra note 316, at art. 21(2).

363 Free Trade Agreement, China-Austl., art. 9.11.4-9.11.6, June 17, 2015 ("Measures of a Party that are non-discriminatory and for the legitimate public welfare objectives of public health, safety, the environment, public morals or public order shall not be the subject of a claim under this Section.") [hereinafter ChinaAustralia FTA]. See also Free Trade Agreement, pmbl., EAEU-Viet., May 29, 2015 (recognizing the need to uphold principles to promote free, non-discriminatory trade practices).

364 Bilateral Investment Treaty, Sing.-Kaz., art. 11(2), Nov. 21, 2018; Free Trade Agreement, Sing.-Austl., art. 22, Dec. 1, 2017 [hereinafter SAFTA]; CPTPP, supra note 45 , at art. 29.5 .

365 See United Nations, Guiding Principles on Business and Human Rights: Implementing the United Nations 'Protect, Respect and Remedy' Framework, U.N. Doc. HR/PUB/11/04 (2011) (ensuring the protection of human rights in business practices).

366 Urbaser v. Argentina, supra note 84, at $\$ 1210$.
} 
For the most part, states that have embraced the concept of investor obligations have tended to take a "soft" approach. A number of treaties include corporate social responsibility provisions that specify that states should "encourage" enterprises to voluntarily incorporate corporate social responsibility standards. ${ }^{367}$ Some treaties have also linked corporate social responsibility to respect for human rights. ${ }^{368}$

Other treaties have moved to hardening investor obligations. For instance, the Brazil-Malawi BIT specifies that investors "shall strive to achieve the highest possible level of contribution to the sustainable development of the Host Party" and outlines methods by which this responsibility can be met including stimulating social progress and facilitating access of workers to training. ${ }^{369}$ Similarly, the draft Pan African Investment Code specifies that investors shall contribute to the economic, social, and environmental progress in the host state as well as ensure that they "do not conflict" with the state's social and economic development. ${ }^{370}$

The Morocco-Nigeria BIT, goes even farther, articulating a specific provision establishing investor obligations. ${ }^{371}$ Under this provision, investors are required to maintain an environmental management system, uphold human rights, act in accordance with internationally recognized labour standards, and refrain from managing or operating their investment in a way that circumvents the state's international environmental, labour, and human rights obligations. ${ }^{372}$ In addition, they are required to engage in a social impact assessment as well as engage in an environmental assessment screening and assessment process for their investments, in accordance with laws set down by either the host or home state (whichever is more rigorous). ${ }^{373}$ Moreover, they are required to refrain from corrupt conduct. ${ }^{374}$ Home states can further hold investors liable for any acts relating to their investment in the host state that causes significant damage, injuries, or loss of life. ${ }^{375}$

The Economic Community of Western African States (ECOWAS) Supplementary Act on Common Investment Rules for

367 See, e.g., Bilateral Investment Treaty, Can.-Mong., art. 14, Sept. 8, 2016; Argentina-Qatar BIT, supra note 310, at art. 12; Hong Kong-Chile BIT, supra note 362 , at art. 16 .

368 See, e.g., Bilateral Investment Treaty Can.-Burk. Faso, art. 16, Apr. 20, 2015; Morocco-Nigeria BIT, supra note 51, at art. 18.

369 Brazil-Malawi BIT, supra note 309, at art. 9; see also Bilateral Investment Treaty, Braz.-Mozam., art. 10, Mar. 30, 2015.

370 Pan-African Inv. Code, Draft, E/ECA/COE/35/18, at art. 22 (2016).

371 Morocco-Nigeria BIT, supra note 51, at art. 18.

372 Id.

373 Id. at art. 14.

374 Id. at art. 17.

375 Id. at art. 20. 
the Community offers an even more elaborate system of investor obligations. ${ }^{376}$ The act devotes an entire chapter to establishing investor obligations. Among others, it requires investors to strive to contribute to the development objectives of the host state; 377 conduct environmental and social impact assessments of the investment prior to its establishment; ${ }^{378}$ refrain from undertaking acts that breach human rights and ensure that management and operation of the investment does not circumvent the states' human rights, labour or environmental obligations; ${ }^{379}$ and refrain from engaging in corruption. ${ }^{380}$ It further ensures that these obligations are legally enforceable by preventing investors who have engaged in corruption from being able to initiate any dispute settlement procedures. ${ }^{381}$ In addition, a state or a private person can enforce the stipulated investor obligations by way of a lawsuit or the investor's conduct can be taken into account in the event of a dispute. ${ }^{382}$

Given the importance of increasing the linkage between foreign investment and a state's development, investor obligations should be included to foster such links. Reliance on "soft" responsibilities "encouraging" investors to be socially responsible are unlikely to foster such links. A better approach is to follow the United Nations Guiding Principles on Business and Human Rights (UNGPs), which stipulates that corporations should refrain from infringing on the human rights of others. ${ }^{383}$ Investors could similarly be required to avoid causing or contributing to human rights or environmental impacts. The UNGPs further stipulate that corporations should prevent or mitigate human rights impacts of their business by, in part, establishing a due diligence process to account for such impacts. ${ }^{384}$ Investors could be tasked with similar responsibilities, requiring them to establish due diligence processes, in accordance with international standards, that seek to prevent, mitigate, and account for human rights and environmental impacts of their investments.

Finally, investor obligations should specify that investors should aim to contribute to a state's sustainable development. In addition, for states particularly in need of securing development from foreign investment, they should supply a nonexhaustive list of how this can be achieved (i.e., by facilitating access to training, technology transfer, etc.). Moreover, unlike the UNGPs, which are

376 See generally ECOWAS, Supplementary Act Adopting Community Rules on Investment and the Modalities for their Implementation, ch. II, A/SA.3/12/08(2008) (dedicating chapter to standards of treatment to member states' investors).

377 Id. at art. 11.3 .

378 Id. at art. 12 .

379 Id. at art. 14.2 .

380 Id. at art. 13 .

381 Id.

382 Id. at art. 18.

383 U.N. Human Rights Council, supra note 99, § 11.

${ }^{384}$ Id. § 15. 
currently not legally enforceable, investor obligations in IIAs should specify that investor failure to adhere to the prescribed conduct will either prevent an investor from being able to initiate an investment arbitral claim, become the subject of a state's counterclaim, and/or result in a proportionate reduction in the amount of any damages awarded. Notably, the new Dutch Model BIT provides that in determining compensation for an award, tribunals may take into account investor noncompliance with commitments under the UN Guiding Principles on Businesses and Human Rights and the OECD Guidelines for Multinational Enterprises. ${ }^{385}$

\section{B. Procedural Reform}

While there is no clear separation in all instances between substantive and procedural reform, this subpart focuses mainly on procedural mechanisms that can enhance state efforts to promote development goals. From the review of cases, it becomes apparent that certain tools were either being used, or could be used, by states to better articulate the policy space needed to regulate development goal-related issues. These include initiating counterclaims, using scientific evidence, using specific experts, and using targeted development promotion provisions.

\section{Counterclaims}

As mentioned earlier, state reliance on counterclaims has proved useful in cases involving environmental or human rights issues. In Perenco, Burlington Resources, Aven, and Urbaser, stateinitiated counterclaims highlighted the environmental issues in the first three disputes and the issue of the right to water in the fourth. Moreover, because the tribunal had to make a determination on the validity of the counterclaim, it was compelled to analyze these noneconomic issues. The initiation of the counterclaim may have therefore prompted tribunal consideration of these noneconomic issues, which may have been otherwise dismissed or downplayed.

Most arbitral rules allow for counterclaims, ${ }^{386}$ but some tribunals have struggled to determine whether counterclaims are

\footnotetext{
385 Netherlands Draft Model BIT, supra note 54, at art. 23.

386 See, e.g., UNCITRAL Arbitration Rules, art. 21.3, U.N. COMM'N ON INT'L TRADE LAW (2014) http://www.uncitral.org/pdf/english/texts/arbitration/arb-rules2013/UNCITRAL-Arbitration-Rules-2013-e.pdf [https://perma.cc/E95Z-YBLL] (archived Oct. 23, 2019); Arbitration Rules, Mediation Rules, art. 5, INT'L CHAMBER OF CoM. (2017), https://cdn.iccwbo.org/content/uploads/sites/3/2017/01/ICC-2017Arbitration-and-2014-Mediation-Rules-english-version.pdf.pdf [https://perma.cc/32ZA-UXQZ] (archived Oct. 23, 2019); Arbitration Rules, art. 9(1)(iii), STOCKHOLM CHAMBer OF COM. (2017); ICSID Convention, supra note 29, at art 46 .
} 
within their jurisdictions. ${ }^{387}$ States that want to ensure counterclaims are accepted should therefore ensure that the definition of the tribunal's jurisdiction extends to counterclaims, either by drafting a broad jurisdiction provision ${ }^{388}$ or by specifically making provision for consideration of counterclaims by tribunals. ${ }^{389}$ Provision for counterclaims also creates an avenue for tribunals to hold investors liable for any investor obligations provided for in the treaty as these can be the subject of counterclaims. ${ }^{390}$

\section{Scientific Evidence}

A second realization from the review of arbitral awards was that, faced with scientific evidence, tribunals were more amenable to considering noneconomic issues. Perhaps this is because scientific evidence "provides a putatively objective basis for assessing the reasonableness of state measures alleged to harm investors' rights." ${ }^{391}$ For instance, in Philip Morris, Chemtura, and Methanex, the tribunal relied heavily on the scientific evidence provided to determine whether the state's actions were justified. ${ }^{392}$ Conversely, in cases such as Windstream, the tribunal chided the state for failing to support its actions with scientific research, ${ }^{393}$ and, in Metalclad, it viewed the lack of scientific evidence as essentially a political sham. ${ }^{394}$ Tribunals may be using scientific evidence, thus, as a proxy for distinguishing legitimate state acts from spurious ones.

States intending to argue that a particular measure was taken to protect a human right or for environmental reasons may wish, therefore, to consider buttressing such measures with scientific evidence, if possible, and enacting the measure in an open and

387 See, e.g., Rusoro Mining Ltd. v. Venezuela, ICSID Case No. ARB(AF)/12/5, , Award, ๆ 627 (Aug. 22 2016) (determining jurisdiction based on the plain text of the Treaty); Spyridon Roussalis v. Romania, ICSID Case No. ARB/06/1, Award, ๆ 868, 871 (Dec. 7, 2011) (determining whether the court has jurisdiction over the case); Vestey Grp. v. Venezuela, ICSID Case No. ARB/06/4, Award, ๆ 333 (Apr. 15, 2016). 388 See Urbaser v. Argentina, supra note 84, at 143 (determining that the tribunal's jurisdiction was broadly defined by "[d]isputes arising between a Party and an investor of the other Party in connection with investments,").

389 See India Model BIT, supra note 55, at art. 14.11 (counterclaims by parties).

$390 \mathrm{See} i d$. at art. 14.11(i) (providing for states to bring counterclaims to enforce investor obligations).

391 Jacqueline Peel, The Use of Science in Environment-Related Investor-State Arbitration, in RESEARCH HANDBOOK ON ENVIRONMENT AND INVESTMENT LAW 5 (K. Miles ed., 2017); Marcos A. Orellana, The Role of Science in Investment Arbitrations Concerning Public Health and the Environment, 17 Y.B. InT'L ENVTL. L. 48 (2006). 392 Methanex Corp. v. United States, supra note 136; Chemtura Corp. v. Canada, supra note 139, at 143.

393 Windstream v. Canada, supra note 222, at 379.

394 See, e.g., Peel, supra note 393, at 13 (arguing that the tribunal assumed that Mexico's ecological decree "was a political sham unsupported by proper (scientific) evidence"). 
informed process. ${ }^{395}$ Moreover, for states with limited technical and economic resources, the Philip Morris tribunal has indicated that they could acquire scientific knowledge from evidence-based public information. ${ }^{396}$ In that dispute, Uruguay had relied on evidence obtained in the course of the negotiations of the World Health Organization Framework Convention on Tobacco Control rather than conducting its own studies. ${ }^{397}$

However, use of scientific evidence will not necessarily guarantee a state's sovereign regulatory powers. In Bilcon, despite Canada providing an evidentiary basis for its measure, the majority of the tribunal still found the state violated its investment treaty obligations. ${ }^{398}$ In particular, it found that Canada's value of the socioeconomic impacts of the investment on the human environment over its scientific and technical feasibility was problematic. ${ }^{399}$ The Bilcon majority thus reviewed Canada's evidence through a narrow technical lens whereas Canada had based its measure on broader evidentiary grounds. As Peel observes, such a lens "may be too narrow to capture the full range of impacts considered relevant by democratic regulatory states." $\mathbf{4 0 0}$

\section{Amicus and Independent Experts}

The review of the arbitral awards also indicated that the presence of amicus curiae in an investment dispute did not necessarily contribute to the tribunal's consideration of human rights or environmental issues. Indeed, in some instances, consideration of these issues occurred without the presence of amicus and in other tribunals continued to discount these issues despite reasoned arguments from amicus. In part, this may be because amicus are generally only granted limited participation rights. ${ }^{401}$ Given this limitation, an alternative approach may be for the tribunal to appoint its own independent expert (selected from a state appointed list)—who would be able to participate more fully in the dispute settlement process-to assist the tribunal with evaluation of noneconomic issues. Experts could, for instance, assist the tribunal with evaluating scientific evidence, determine the socioeconomic impacts of a measure, or help the tribunal determine whether a particular measure is oriented towards a

\footnotetext{
395 Methanex Corp. v. United States, supra note 136, at 101.

396 Philip Morris v. Uruguay, supra note 84, at 9 393-94.

397 Id.

398 Bilcon v. Canada, supra note 191, at $₫ 534$.

399 Id.

400 Peel, supra note 393, at 20.

401 See, e.g., Lucas Bastin, Amici Curiae in Investor-State Arbitration: Eight Recent Trends, 30 ARB. INT'L 125, 137 (2017); Eugenia Levine, Amicus Curiae in International Investment Arbitration: The Implications of an Increase in ThirdParty Participation, 29 BERKELEY J. INT'L. L. 200, 207 (2011).
} 
legitimate public welfare objective. Their role would be thus to ensure that proper consideration is given by the tribunal to noneconomic issues.

Several arbitral rules already provide for appointment of independent experts. ${ }^{402}$ Building on this practice, IIAs could similarly provide that, in investment arbitrations involving public welfare objectives, tribunals should seek the assistance of an independent human rights or environmental expert.

\section{Targeted Provisions}

A final option for reform includes the addition of provisions targeted at promoting development goals. For instance, IIAs could contain provisions requiring investors to engage in human rights and/or environmental impact assessments prior to investing, or they could specify provisions that build on denial of benefits clauses-for example, as found in the NAFTA ${ }^{403}$ - to prevent investors from benefitting from the IIA if they have caused significant adverse human rights or environmental impacts. Additionally, they could stipulate that, in determining the compensation of an award, the tribunal must consider whether the investor has engaged in adverse human rights impacts or environmental damage. ${ }^{404}$

Developing countries may also wish to consider negotiating for special and differentiated treatment that would offer them more leeway in the application of investment standards. Special and differentiated treatment is well established under the WTO rules, ${ }^{405}$ yet IIAs do not offer comparable treatment. As Cai notes, BITs "leave no room for due regard for the special circumstances of host states in prescribing a BIT obligation (in particular, a 'minimum' standard of treatment)." ${ }^{406}$ Inclusion of reference to special and differentiated treatment could compel, for instance, arbitral tribunals to consider the host state's level of development in determining breaches of IIAs, ${ }^{407}$ leaving more room for these

402 See, e.g., IBA Rules on the Taking of Evidence in International Arbitration, INT'L BAR Ass'N, art. 6(1) (2010); Optional Rules For Arbitrating Disputes Between Two Parties Of Which Only One Is A State, PERMAnent CT. ARB., arts. 27.1, 24.4 (1993); UNCITRAL Arbitration Rules, supra note 388, at art. 27.

403 See, e.g., NAFTA, supra note 45, at art. 113.

404 See, e.g., the model BIT proposed by Ecuador which requires tribunals to consider environmental damage as part of determining compensation for an expropriation. See Javier Jaramillo, New Model BIT proposed by Ecuador: Is the Cure Worse than the Disease?, KLUWER ARB. BLOG (July 20, 2018) http://arbitrationblog.kluwerarbitration.com/2018/07/20/new-model-bit-proposedecuador-cure-worse-disease/ [https://perma.cc/HP8Z-PNQQ] (archived Nov. 2, 2019) (noting in order to quantify the compensation for the investment, the tribunal must consider factors including the fault of the investor in the damages caused and any type of environmental damage).

405 See, e.g., Alexander Keck \& Patrick Low, Special and differential treatment in the WTO: Why, when and how? 3 (WTO Staff Working Paper, No. ERSD-2004-03, 2004) (detailing how special and differential treatment evolved in the WTO system). 406 Cai, supra note 303, at 221.

407 Id. 
states to engage in regulatory measures aimed at promoting development goals.

Moreover, in treaties between developed and developing countries, states could include provisions requiring the developed state to actively promote and facilitate investment in the developing state and to cooperate with it "to transfer technology to and build capacity ... [in the state] . . . to host and benefit from foreign investment." 408 Indeed, the idea of facilitating more interaction between the contracting states is the practice taken in Brazilian IIAs. ${ }^{409}$ Brazil has adopted the approach of using joint committees (composed of state parties) to share opportunities to expand mutual investment and to cooperate to facilitate investment ${ }^{410}$ and the use of ombudsmen to support investors while in the host state. ${ }^{411}$ These practices enhance capacity building in the states as well as help states adhere to their IIA obligations. ${ }^{412}$

\section{Reform of ISDS}

The UNCITRAL Working Group on Investor-State Dispute Settlement Reform, among others, have made numerous efforts to address ISDS reform. ${ }^{413}$ This subpart, therefore, only examines reform of ISDS in terms of development goals.

A first observation is that, although there has been much speculation that the identity characteristics of arbitrators is one of the problems with the overall ISDS process, the reviewed awards indicate that this is not necessarily true in relation to the promotion of development issues. The review did not indicate, for instance, that female arbitrators or arbitrators originating from developing countries were more likely to take into account human rights or environmental issues in their interpretation of investment

408 Nathalie Bernasconi-Osterwalder \& Lise Johnson, Commentary to the Austrian Model Investment Treaty, 36 InT'L Inst. FOR SustainABLE DeV. 36 (Sept. 2011), https://www.iisd.org/pdf/2012/austrian_model_treaty.pdf [https://perma.cc/D5UUC635] (archived Nov. 2 2019).

409 See Henrique C. Moraes \& Felipe Hees, Breaking the BIT Mold: Brazil's Pioneering Approach to Investment Agreements, 112 AM. J. INT'L L. BLOG 197 (2018) (noting the Brazilian investment agreement breaks the BIT mold by shifting the focus from investment protection to facilitation).

410 See, e.g., Brazil-Malawi BIT, supra note 309, at art. 3.4.

411 Id. at art. 4.

412 Cai, supra note 303 , at 221.

413 See, e.g., Possible Reform of Investor-State Dispute Settlement - Note by the Secretariat, UNCITRAL WORKING GROUP III, U.N. Doc. A/CN.9/WG.III/WP.149, ๆ 5 (Sept. 5 2018) [hereinafter UNCITRAL Working Group III]; David Gaukrodger, Appointing Authorities and the Selection of Arbitrators in Investor-State Dispute Settlement: An Overview - Consultation Paper, OECD (2018); Investment-Related Dispute Settlement: Lessons from International Accountability Mechanisms, IISD 4 (2017), https://www.iisd.org/sites/default/files/publications/investment-relateddispute-settlement-iisd-auwcl-expert-meeting-washington-dc.pdf [https://perma.cc/5RMB-46J8] (archived Nov. 2, 2019). 
treaties. Indeed, some of the cases involving the greatest recognition of noneconomic interests, such as Philip Morris or Methanex, involved male arbitrators from developed countries. ${ }^{414}$ Conversely, the reviewed awards did indicate a trend that arbitrators with a judicial or academic background were more likely to take into account noneconomic issues. ${ }^{415}$ This trend aligns generally with the concerns in the UNCITRAL's working group's report on problems relating to arbitrator's competence and qualifications. As the working group found, arbitrators should have the "ability to take into account relevant issues of public interest or public policy," which are often at stake in investment arbitrations..$^{416}$ The reviewed awards also seemed to suggest that arbitrators from a predominantly commercial background were less likely to engage with public policy issues than an arbitrator with an academic background who may be more familiar with such issues. ${ }^{417}$ Accordingly, one ISDS reform option could be to increase the number of arbitrators without a predominantly commercial background in order to promote development goals.

Moreover, since investment arbitration is the root cause, in many instances of pitting investment and development issues against one another, a second possibility for reform is to remove ISDS either in part or wholly. One option would be, as mentioned above, to remove ISDS as a dispute resolution mechanism for public welfare regulations generally or for specific regulations designed to meet development goals, such as in relation to tobacco control measures. ${ }^{418}$ Alternatively, states can remove ISDS entirely from their investment policies. Thus, Brazil has removed ISDS entirely from its IIAs, ${ }^{419}$ as have Canada and the United States and Mexico for disputes between them in the newly

414 See, e.g., the all-male arbitral tribunals in Philip Morris v. Uruguay (Piero Bernardini, Gary Born, James Crawford) and Methanex v. United States (William Rowley, Warren Christopher and V.V. Veeder).

415 See, e.g., the following arbitrations where non-economic issues were recognized: Urbaser v. Argentina (two professors on the arbitral tribunal); Philip Morris v. Uruguay (two professors on the arbitral tribunal); Chemtura v. Canada (two professors on the arbitral tribunal); Wirtgen v. Czech Republic (one professor and one judge on the arbitral tribunal); LG\&E v. Argentina (one professor and one judge on the arbitral tribunal).

416 Gaukrodger, supra note 415 , at 931 .

417 See, e.g., Wirtgen v. Czech Republic where the arbitrator with the strictly commercial background dissented from the recognition of non-economic issues by the otherwise academic/judicial background tribunal. Compare also LG\&E v. Argentina to CMS v. Argentina, in which the same set of facts gave rise to two different results. In LG\&E, the arbitral tribunal with a judicial/academic background recognized the noneconomic issues in the dispute whereas in CMS, the arbitral tribunal with the commercial background did not.

418 See, e.g., CPTPP, supra note 45, at art. 29.5; China-Australia FTA, supra note 365, at art. 9.11.4-9.11.6.

419 See, e.g., South Africa Dep't Trade \& Industry, Bilateral Investment Treaty Policy Framework Review, pt. II (June 2009); Brazil-Malawi BIT, supra note 309, at art. 3. 
reconstituted NAFTA, now known as USMCA. ${ }^{420}$ South Africa has similarly eschewed ISDS, favouring instead the settlement of investment disputes in its domestic courts and state-to-state dispute settlement. ${ }^{421}$ Indeed, it has abandoned reliance on IIAs entirely, replacing them with foreign investment protection in its domestic laws, where it limits foreign investor protection drastically. ${ }^{422}$ Notably, despite South Africa's departure from the BIT regime, foreign investment has surged in the country. ${ }^{423}$

In light of Brazil and South Africa's favourable experiences and the new practice espoused in the USMCA, states may wish to review whether the full menu of the ISDS regime is necessary. In particular, the Brazilian approach may offer a compromise between foreign investor protection and sovereign control over foreign investment regulation. By removing ISDS, Brazil has prevented arbitral tribunals from being able to engage in curtailments of the state's regulatory power, yet it still manages to ensure foreign investors can have their grievances and disputes settled in a specialized forum. The Brazilian approach could therefore offer an attractive precedent for states seeking to achieve a more balanced approach to ISDS.

\section{CONCLUSION}

Since their modern inception, investment treaties have been clear that economic development is an integral aspect of them. In today's world, where economic development is viewed more broadly and incorporates ideas of sustainable development as well, investment treaties must therefore also include notions of sustainable development within their ambit.

While investor protection remains a key element of investment treaties, it is questionable whether it is the ultimate aim, or simply a means to a greater end: namely, economic and sustainable development. Indeed, given the limited empirical evidence demonstrating the clear links between investment treaties and a state's receipt of foreign direct investment as well as the renewed power of foreign investors vis-à-vis states, it seems apparent that

420 Agreement between the United States, the United Mexican States, and Canada, U.S.-Mex.-Can., ch. 14, Annex 14-C (Nov. 30, 2018) https://ustr.gov/tradeagreements/free-trade-agreements/united-states-mexico-canada-

agreement/agreement-between [https://perma.cc/S77Y-G585] (archived Nov. 2, 2019).

421 Protection of Investment Act No. 22 of 2015 (S. Afr.), https://www.gov.za/sites/default/files/gcis_document/201512/39514act22of2015prot ectionofinvestmentact.pdf [https://perma.cc/US4C-VQA8] (archived Nov. 2, 2019). 422 Id.

423 U.N. Conf. On TRADE \& DeV., Global Investment Trends Monitor No. 255 (Feb. 1, 2017), http://unctad.org/en/Pages/DIAE/Research\%20on\%20FDI\% 20and\%20TNCs/Global-Investment-Trends-Monitor.aspx [https://perma.cc/YWX6L2ER] (archived Nov. 2, 2019). 
it is time to retire the traditional view of investment treaties as the only vehicles for the protection of investors/investment.

In particular, if investment treaties are viewed through a lens of more than just investor protection, it is clear that such treaties should be tools for promoting economic and sustainable development within a state. At a minimum, they should not be vehicles thwarting such development.

The review of investment arbitration awards involving noneconomic issues suggests, however, that development ideals are being compromised in investment disputes. This is occurring because tribunals are either failing to engage with such noneconomic issues or discounting or ignoring these issues in their analysis. This is surprising given that international law provides for systemic integration, requiring tribunals to consider and take into account noneconomic issues, insofar as they are reflected in the wider body of the rules of international law. Indeed, while international law provides for the consideration of these issues in the interpretation of investment treaties, tribunals are clearly, in some instances, failing to do so.

For that reason, states should take the initiative to delineate development goals in the text of treaties to ensure that tribunals must consider such noneconomic issues. This can be accomplished by inserting right-to-regulate provisions, limiting or qualifying fair and equitable provisions, adding safeguard provisions, and delineating investor obligations. In addition, states can add provisions enabling counterclaims, buttress state regulations with objective evidence, provide for independent experts with human rights or environmental expertise, include targeted provisions aimed at promoting development goals, and reform ISDS by specifying the qualifications of arbitrators and by removing it as a form of dispute resolution either for development-related provisions only or entirely.

While it is up to each individual state to determine which options for reform best suit its investment policy goals-as some of the suggested options may not be optimal for every state-it is clear that the time is ripe for all states to realize the importance of development objectives to the overall investment regime. Failure to do so poses increasing human rights and environmental risks for both developed and developing countries.

Appendix 1: Investment Arbitrations Involving Human Rights and/or Environmental Issues

\begin{tabular}{|c|c|c|c|c|c|c|c|}
\hline Name & Arbitrators & $\begin{array}{l}\text { Noneconomic } \\
\text { issues involved }\end{array}$ & $\begin{array}{l}\text { Counter- } \\
\text { claim }\end{array}$ & Amicus & FET & $\begin{array}{l}\text { Expropri } \\
\text {-ation }\end{array}$ & Damages \\
\hline Azurix Corp. v. Argentine & Andrés Rigo Sureda, & Water & $\mathrm{N}$ & $\mathrm{N}$ & Breach & No & USD \\
\hline Republic, ICSID Case No & Lalonde, & & & & found & breach & $\$ 165,240,753$ \\
\hline ARB/01/12, Award (14 July & Daniel & & & & & found & \\
\hline 2006) & Martins & & & & & & \\
\hline
\end{tabular}




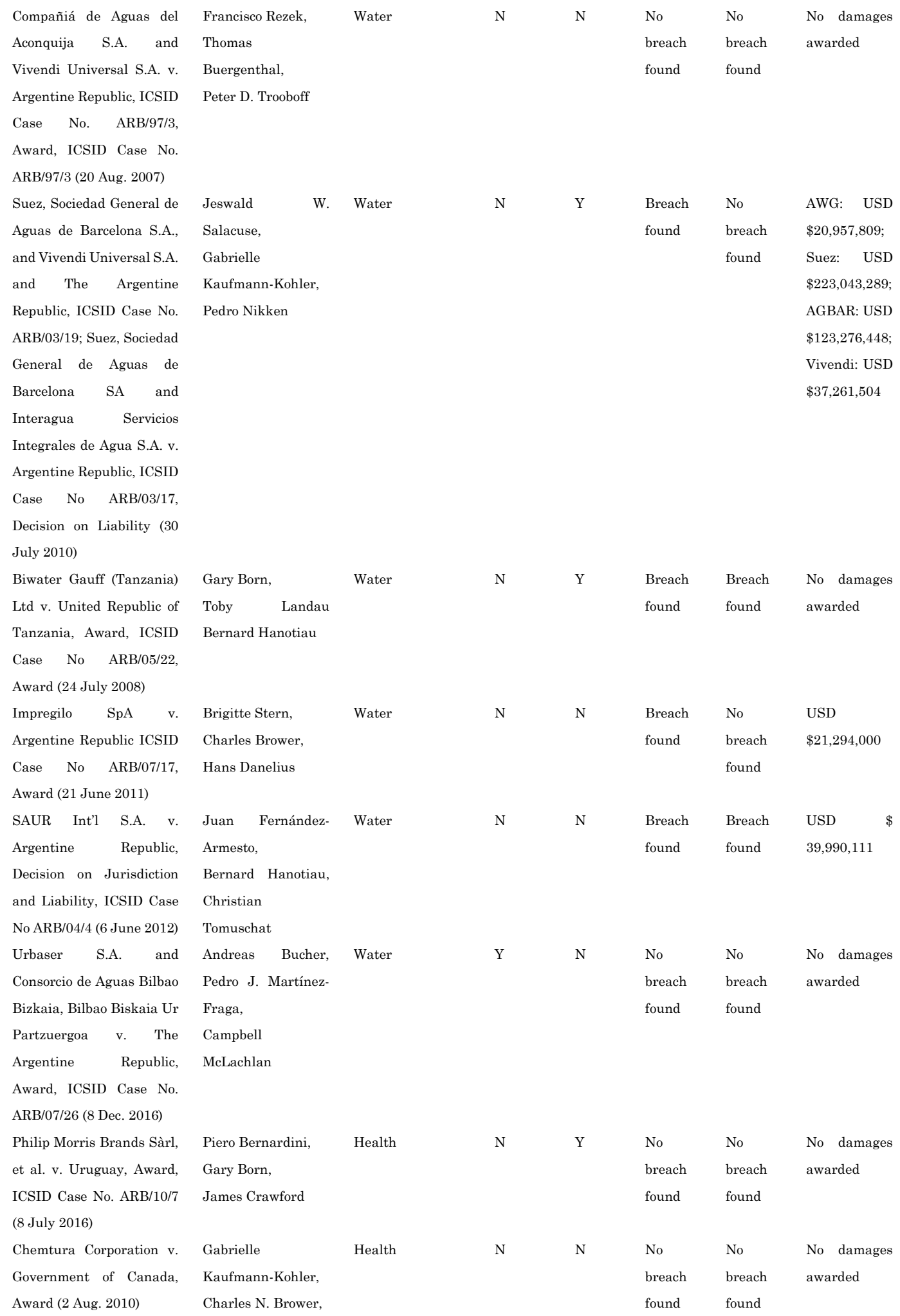




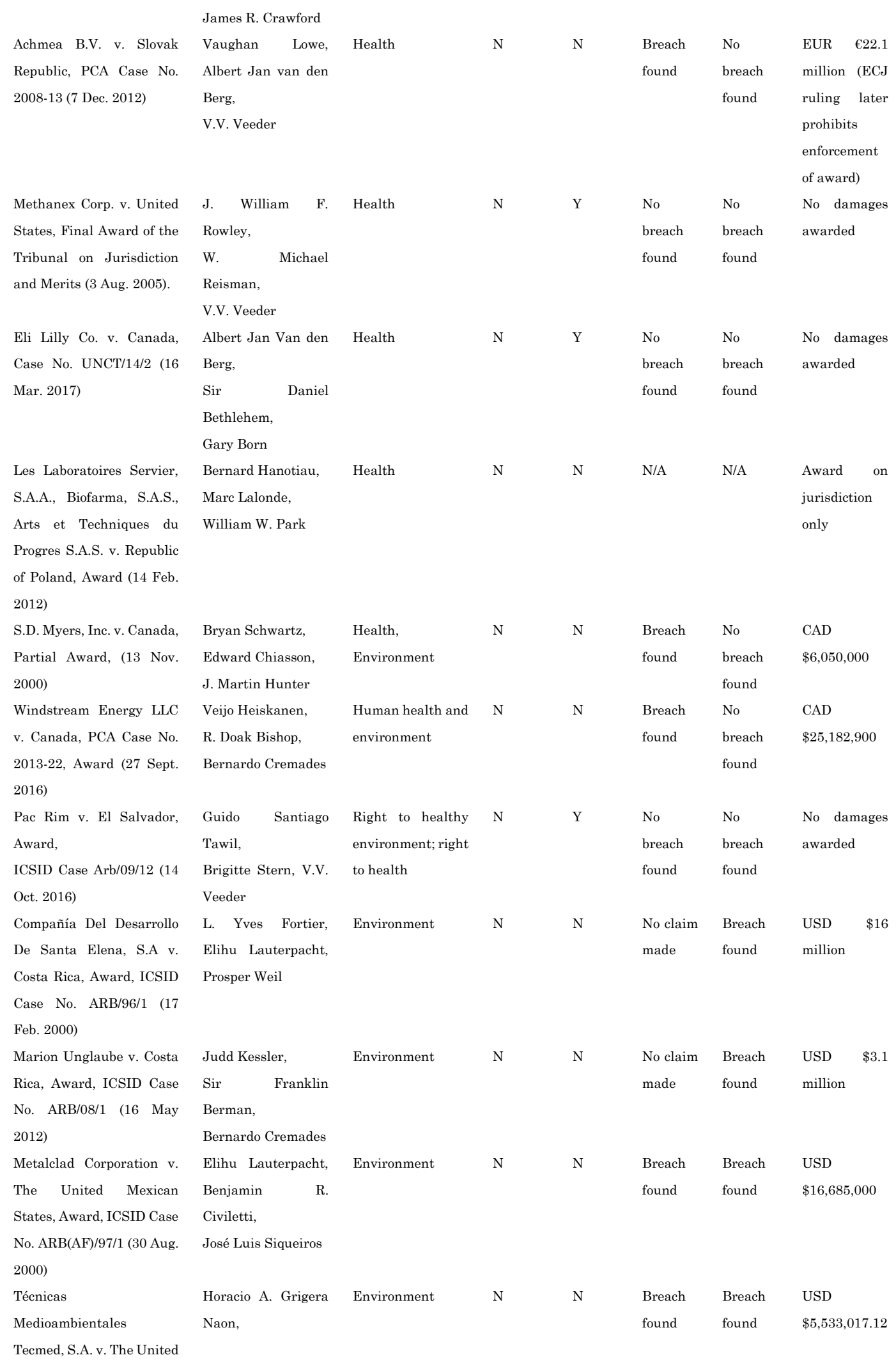




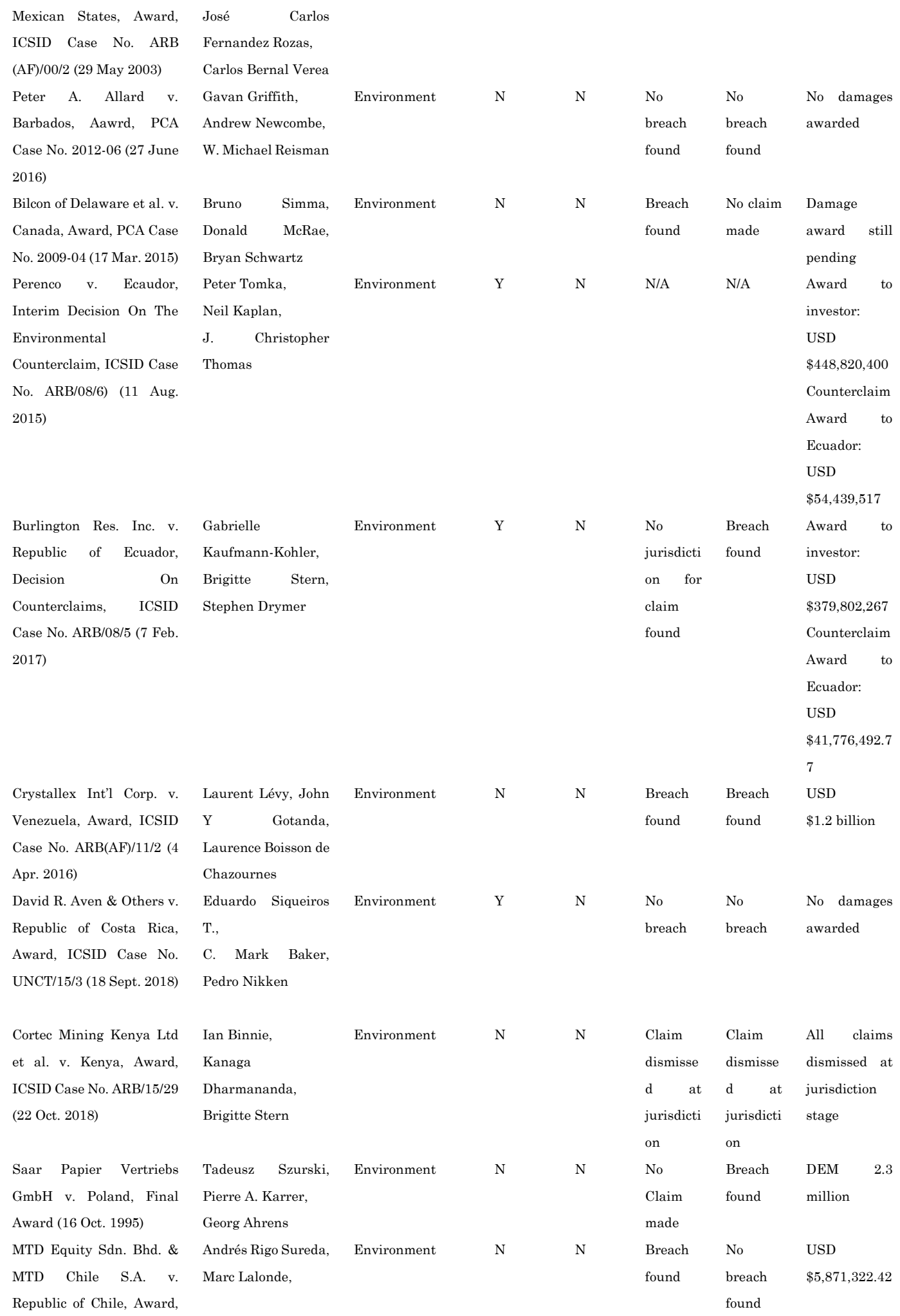




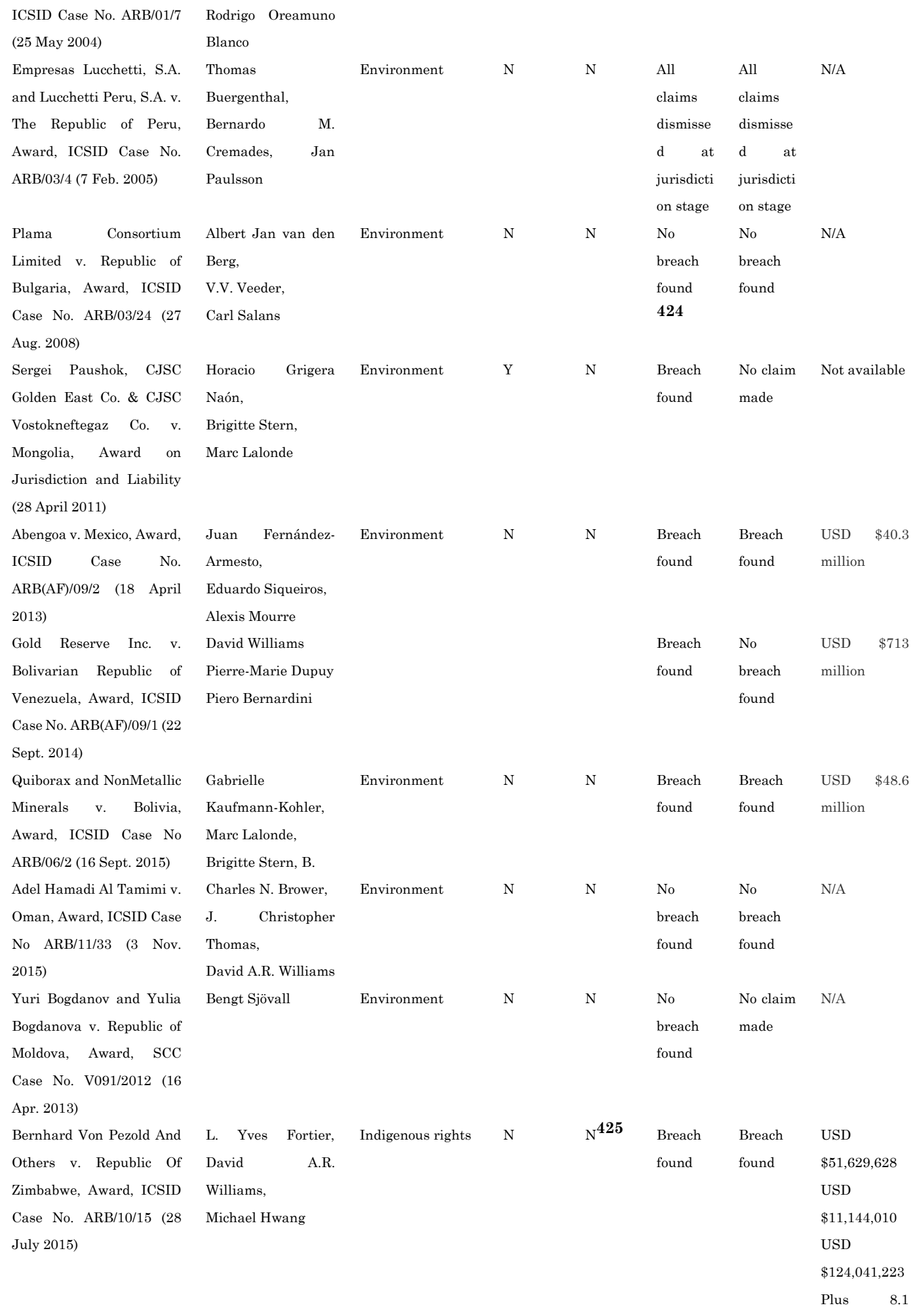

424 The Tribunal found the investor was not entitled to rely on the Energy Charter Treaty, but in any case, its claims did not have merit.

425 Indigenous communities were denied amicus status. 


\begin{tabular}{|c|c|c|c|c|c|c|c|}
\hline & & & & & & & $\begin{array}{l}\text { million for } \\
\text { moral } \\
\text { damages and } \\
\text { loans }\end{array}$ \\
\hline $\begin{array}{l}\text { Grand River Enterprises } \\
\text { Six Nations, Ltd., et al. v. } \\
\text { United States Of America, } \\
\text { Award (Jan } 12,2011 \text { ) }\end{array}$ & $\begin{array}{l}\text { Fali S. Nariman, } \\
\text { James Anaya, John } \\
\text { R. Crook }\end{array}$ & Indigenous rights & $\mathrm{N}$ & $\mathrm{Y}$ & $\begin{array}{l}\text { No } \\
\text { breach } \\
\text { found }\end{array}$ & $\begin{array}{l}\text { No } \\
\text { breach } \\
\text { found }\end{array}$ & $\begin{array}{l}\text { No damages } \\
\text { awarded }\end{array}$ \\
\hline $\begin{array}{l}\text { Glamis Gold, Ltd. v. } \\
\text { United States of America, } \\
\text { Award, (8 June 2009) }\end{array}$ & $\begin{array}{l}\text { Michael K. Young, } \\
\text { David D. Caron, } \\
\text { Kenneth D. } \\
\text { Hubbard }\end{array}$ & Indigenous rights & $\mathrm{N}$ & $\mathrm{Y}$ & $\begin{array}{l}\text { No } \\
\text { breach } \\
\text { found }\end{array}$ & $\begin{array}{l}\text { No } \\
\text { breach } \\
\text { found }\end{array}$ & $\begin{array}{l}\text { No damages } \\
\text { awarded }\end{array}$ \\
\hline $\begin{array}{l}\text { Bear Creek Mining Corp. } \\
\text { v. Republic of Peru, Award, } \\
\text { ICSID Case No. ARB/14/2, } \\
\text { (30 Nov. 2017) }\end{array}$ & $\begin{array}{l}\text { Karl-Heinz } \\
\text { Böckstiegel, Michael } \\
\text { Pryles, Philippe } \\
\text { Sands }\end{array}$ & Indigenous rights & $\mathrm{N}$ & $\mathrm{Y}$ & $\begin{array}{l}\text { Claim } \\
\text { not } \\
\text { consider } \\
\text { ed }^{\mathbf{4 2 6} 6}\end{array}$ & $\begin{array}{l}\text { Breach } \\
\text { found }\end{array}$ & $\begin{array}{l}\text { USD } \\
\$ 18,237,592\end{array}$ \\
\hline $\begin{array}{l}\text { Copper Mesa Mining Corp. } \\
\text { v. Republic of Ecuador, } \\
\text { Award, PCA No. 2012-2 } \\
\text { (15 Mar. 2016) }\end{array}$ & $\begin{array}{l}\text { Bernardo } \\
\text { Cremades, } \\
\text { Bruno Simma V.V. } \\
\text { Veeder }\end{array}$ & $\begin{array}{l}\text { Indigenous rights, } \\
\text { Environment }\end{array}$ & $\mathrm{N}$ & $\mathrm{N}$ & $\begin{array}{l}\text { Breach } \\
\text { found }\end{array}$ & $\begin{array}{l}\text { Breach } \\
\text { found }\end{array}$ & $\begin{array}{l}\text { USD } \\
\$ 19,447,494\end{array}$ \\
\hline $\begin{array}{l}\text { SPP v. Egypt, Award, } \\
\text { ICSID Case No. ARB/84/3 } \\
(20 \text { May 1992) }\end{array}$ & $\begin{array}{l}\text { Eduardo Jimenez } \\
\text { De Arechaga, } \\
\text { Mohamed Amin El } \\
\text { Mahdi, } \\
\text { Nassib G. Ziade }\end{array}$ & Culture & $\begin{array}{l}\text { Y (but on } \\
\text { grounds } \\
\text { other } \\
\text { than } \\
\text { culture) }\end{array}$ & $\mathrm{N}$ & $\begin{array}{l}\text { No claim } \\
\text { made }\end{array}$ & $\begin{array}{l}\text { Breach } \\
\text { found }\end{array}$ & $\begin{array}{l}\text { USD } \\
\$ 27,661,000\end{array}$ \\
\hline $\begin{array}{l}\text { Parkerings-Compagniet } \\
\text { AS v. Republic of } \\
\text { Lithuania, Award, ICSID } \\
\text { Case No. ARB/05/8 (11 } \\
\text { Sept. 2007) }\end{array}$ & $\begin{array}{l}\text { Julian Lew, } \\
\text { Marc Lalonde, } \\
\text { Laurent Lévy }\end{array}$ & Culture & $\mathrm{N}$ & $\mathrm{N}$ & $\begin{array}{l}\text { Claim } \\
\text { dismisse } \\
\text { d }\end{array}$ & $\begin{array}{l}\text { Claim } \\
\text { dismisse } \\
\text { d }\end{array}$ & $\begin{array}{l}\text { No damages } \\
\text { awarded }\end{array}$ \\
\hline $\begin{array}{l}\text { Jürgen Wirtgen, Stefan } \\
\text { Wirtgen, Gisela Wirtgen } \\
\text { and JSW Solar (zwei) } \\
\text { GmbH \& Co. KG v. Czech } \\
\text { Republic, Final Award, } \\
\text { PCA Case No. 2014-03 (11 } \\
\text { Oct. 2017). }\end{array}$ & $\begin{array}{l}\text { Gabrielle } \\
\text { Kaufmann-Kohler, } \\
\text { Gary Born, } \\
\text { Peter Tomka }\end{array}$ & $\begin{array}{l}\text { Social implications } \\
\text { of financial crisis }\end{array}$ & & & $\begin{array}{l}\text { Claim } \\
\text { dismisse } \\
\text { d }\end{array}$ & & $\begin{array}{l}\text { No damages } \\
\text { awarded }\end{array}$ \\
\hline $\begin{array}{l}\text { CMS Gas Transmission } \\
\text { Co. v. Argentine Republic, } \\
\text { ICSID Case No. ARB/01/8, } \\
\text { Award (12 May 2005) }\end{array}$ & $\begin{array}{l}\text { Francisco Orrego } \\
\text { Vicuña, } \\
\text { Marc Lalonde, } \\
\text { Francisco Rezek }\end{array}$ & $\begin{array}{l}\text { Social implications } \\
\text { of financial crisis }\end{array}$ & $\mathrm{N}$ & $\mathrm{N}$ & $\begin{array}{l}\text { Breach } \\
\text { found }\end{array}$ & $\begin{array}{l}\text { Claim } \\
\text { dismisse } \\
\text { d }\end{array}$ & $\begin{array}{l}\text { USD } \\
\$ 133.2 \\
\text { million }\end{array}$ \\
\hline $\begin{array}{ll}\text { LG\&E Energy } & \text { Corp. v. } \\
\text { Argentine } & \text { Republic, } \\
\text { Decision on Liability, } \\
\text { ICSID Case No. ARB/02/1 } \\
\text { (3 Oct. 2006) }\end{array}$ & $\begin{array}{l}\text { Tatiana B. de } \\
\text { Maekelt } \\
\text { Francisco Rezek, } \\
\text { Albert Jan van den } \\
\text { Berg }\end{array}$ & $\begin{array}{l}\text { Social implications } \\
\text { of financial crisis }\end{array}$ & & & $\begin{array}{l}\text { Breach } \\
\text { found }\end{array}$ & $\begin{array}{l}\text { No } \\
\text { breach } \\
\text { found }\end{array}$ & $\begin{array}{l}\text { USD } \$ 57.4 \\
\text { million }\end{array}$ \\
\hline
\end{tabular}




\begin{tabular}{|c|c|c|}
\hline Enron Corp. Ponderosa & Francisco Orrego- & Social implications \\
\hline Asset, L.P. v. Argentine & Vicuña, & of financial crisis \\
\hline Republic, Award, ICSID & Albert Jan van den & \\
\hline Case No. ARB/01/3, Award & Berg, & \\
\hline (22 May 2007) & Pierre-Yves Tschanz & \\
\hline Sempra Energy Int'l v. & Francisco & Social implications \\
\hline Argentine Republic, ICSID & Vicuña, & of financial crisis \\
\hline Case No. ARB/02/16, & Marc Lalonde, & \\
\hline Award (Sept. 28, 2007) & Sandra Morelli Rico & \\
\hline BG Group PLC v. The & Alejandro M. Garro & Social implications \\
\hline Republic of Argentina, & Albert Jan Van Den & of financial crisis \\
\hline Final Award (Dec. 24, 2007 & Berg, & \\
\hline & Guillermo Aguilar & \\
\hline & Alvarez & \\
\hline Metalpar S.A. and Buen & Rodrigo Oreamuno & Social implications \\
\hline Aire S.A. v. The Argentine & Blanco, Duncan H. & of financial crisis \\
\hline Republic, Award on the & Cameron, Jean Paul & \\
\hline Merits, ICSID Case No. & Chabaneix & \\
\hline ARB/03/5 ( 6 Jun 2008) & & \\
\hline Cont'l Cas. Co. v. The & Giorgio Sacerdoti,. & Social implications \\
\hline Argentine & V.V. Veeder, Michell & of financial crisis \\
\hline Award, ICSID Case No. & Nader & \\
\hline ARB/03/9 (5 Sept. 2008). & & \\
\hline National Grid plc v. & Alejandro & Social implications \\
\hline Argentine & Garro, & of financial crisis \\
\hline Award, (3 Nov. 2008) & Judd L. Kessler, & \\
\hline & Andrés Rigo Sureda & \\
\hline Siemens A.G. v. The & Andrés Rigo Sureda, & Social implications \\
\hline Argentine & Charles N. Brower, & of financial crisis \\
\hline Award, ICSID Case No. & Bello Janeiro & \\
\hline ARB/02/8 (17 Jan. 2007) & & \\
\hline
\end{tabular}

El Paso Energy Int'l Co. v. The Argentine Republic, Award, ICSID Case No. ARB/03/15 (31 Oct. 2011)

Total S.A. v. The Argentine Republic, Decision on Liability, ICSID Case No. ARB/04/01 (27 Dec. 2010)

Piero Bernardini
Brigitte Stern
Lucius Caflisch
Henri Alvarez
Luis Herrera
Marcano
Giorgio Sacerdoti

Social implications of financial crisis

Social implications $\quad \mathrm{Y}$ of financial crisis

Giorgio Sacerdoti

$\begin{array}{lll}\begin{array}{l}\text { Breach } \\ \text { found }\end{array} & \begin{array}{l}\text { No } \\ \text { breach } \\ \text { found }\end{array} & \begin{array}{l}\text { USD } \$ 106.20 \\ \text { million } \\ \text { (Award later } \\ \text { annulled) }\end{array} \\ & & \\ \text { Breach } & \text { No } & \text { USD } \\ \text { found } & \text { breach } & \$ 128,250,462 \\ & \text { found } & \text { (Award later } \\ & & \begin{array}{l}\text { annulled) } \\ \text { Breach }\end{array} \\ \text { found } & \text { No } & \text { USD } \\ & \text { breach } & \$ 185,285,485 \\ & \text { found } & \end{array}$

$\begin{array}{lll}\text { No } & \text { No } & \text { No damages } \\ \text { breach } & \text { breach } & \text { awarded } \\ \text { found } & \text { found } & \end{array}$

$\begin{array}{llll}\text { Breach No } & \text { USD } & \$ 2.8\end{array}$

found breach million

found

Breach No USD

found breach $\$ 53,592,439.2$

found 5

Breach Breach USD

found found $\$ 208,440,540$

on account of the value of its investment, US $\$ 9,178,000$ USD $\$ 43.03$

found breach million

found

Breach No US $\$ 269.90$

found breach million

found 